\title{
James Leeke, George Herbert, and the Neo-Latin Contexts of The Church Militant
}

\author{
LINDSAY G. GIBSON, JOHN KUHN
}

This article situates George Herbert's poem The Church Militant in new Neo-Latin contexts. Rather than reading the poem in relation to Herbert's English poetry, as has often been done before, it argues that it has close generic ties to Anglo-Latin miniature epics on the Gunpowder Plot. This article first shows how Herbert's English poem draws on and revises elements of this tradition; it then turns to a little-known manuscript translation of The Church Militant prepared immediately after its publication. The translation - which significantly revises Herbert's original text - attempts to pull Herbert's poem closer to the miniature epic tradition from which it had broken. Taken together, these contexts demonstrate the surprising proximity of this English poem to a Neo-Latin poetic genre and shed new light on Herbert's choice of the vernacular as a departure from the politics of the miniature epic tradition. ${ }^{*}$

\section{Introduction}

No poem fits less easily into George Herbert's canon than The Church Militant. The poem, which first appeared in print at the end of Herbert's posthumous magnum opus, The Temple, is an apocalyptic world history of the migrations of the true church, who finds herself continually dogged by corruption as she moves westward across millennia. The poem's length and narrative strangeness, its investment in contemporary ecclesiastical politics and, most of all, its polemical account of the English church's corruption have troubled generations of readers who know Herbert for his short, meditative lyrics and the mainstream "high church" politics that resulted in his later canonization as an Anglican saint. Though the poem has not attracted the same amount of attention as Herbert's other works, scholars who have attended to it have tended to fixate on this political and aesthetic discontinuity between the poem and the larger collection of English poetry in which it was first printed. They

* The authors would like to thank the editorial staff of Humanistica Lovaniensia, especially Victoria Moul and Jeroen De Keyser, for their helpful and transformative feedback, as well as Durham University's Institute for Medieval and Early Modern Studies, which provided some financial support for this project. 
have responded to this gap either by developing elaborate interpretive schemes to account for the relationship between the poem and the collection or by argumentatively - and even editorially - distancing it from the collection altogether. ${ }^{1}$ In this article, we suggest that the critical focus on this relationship has, somewhat counterproductively, occluded the generic relationship between The Church Militant and its most immediate poetic context: the tradition of Anglo-Latin university poetry in which the young Herbert was steeped and from which, we argue here, this most curious poem emerges.

We first argue that Herbert's English poem is modeled on the NeoLatin miniature epic tradition - especially a group of shorter AngloLatin epics on the Gunpowder Plot - from which it borrows formal elements while breaking from the genre's nationalist and anti-Catholic politics. We then discuss the poem's transformation into a Neo-Latin epic of the kind that influenced its composition: a puzzling and littleknown Latin translation of Herbert's poem, made soon after the initial publication of The Temple. We suggest that the translator, James Leeke, was engaged in what might be called generic revanchism, attempting to

\footnotetext{
${ }^{1}$ For a history and analysis of these attempts to include or exclude the poem from The Temple, see the useful critical summary in J.G. Harris, Untimely Matter in the Time of Shakespeare (Philadelphia, PA, 2010), 58-59. Only a small handful of scholars have addressed the poem in other terms. Anselment and Hovey provide close-readings or explications of the poem but do not link it to other generic contexts. Shuger argues that Herbert's source text may have been Otto von Freising's prose history The Two Cities, but does not comment on genre. Hodgkins and Malcolmson have commented on the poem's relationship to the Stuart colonial moment, but neither take up the question of genre. The only discussions of the poem's relationship to Herbert's other poetry are brief mentions in two separate articles by Hovey, who connects it to Inventa bellica and the Queen of Bohemia poems, Malcolmson's short discussion in George Herbert. A Literary Life, and Kuhn's suggestion that the poem shares tonal and topical common ground with Herbert's Latin elegies for his mother. See R. Anselment, "The Church Militant. George Herbert and the Metamorphoses of Christian History", Huntington Library Quarterly 41.4 (1978), 299-316; K.A. Hovey, "Wheel'd about... into Amen. The Church Militant on Its Own Terms", George Herbert Journal 10 (1986), 71-84; D.K. Shuger, Habits of Thought in the English Renaissance (Toronto, 1997), 106-112; C. Hodgkins, Reforming Empire. Protestant Colonialism and Conscience in British Literature (Columbia, MO, 2002), 152-153; C. Malcolmson, Heart-Work. George Herbert and the Protestant Ethic (Palo Alto, CA, 1999), 198-202; J. Kuhn, "Left Behind. George Herbert, Eschatology, and the Stuart Atlantic, 1606-1634", in A. Crome (ed.), Prophecy and Eschatology in the Transatlantic World, 1550-1800 (London, 2016), 69-72; K.A. Hovey, "George Herbert's Authorship of To the Queene of Bohemia", Renaissance Quarterly 30.1 (1977), 43-50; Id., "Inventa Bellica / Triumphus Mortis. Herbert's Parody of Human Progress and Dialogue with Divine Grace", Studies in Philology 78.3 (1981), 275-304; C. Malcolmson, George Herbert. A Literary Life (Basingstoke, 2005), 71-72.
} 
pull The Church Militant back in line with the politics and aesthetics of the Latin mini-epic tradition from which Herbert had deliberately broken. With this translation, Leeke - who was himself situated within a network of Arminian ministers - produced a more emphatically nationalist and less ecclesiastically controversial version of Herbert's poem, softening its critiques of the English church and of ceremonial practices while amplifying its anti-Catholic content, perhaps with an eye to producing a more "acceptable" Herbert for international circulation. Demonstrating The Church Militant's proximity to this Neo-Latin genre raises pressing, perhaps unexpected questions about Herbert's choice to compose the poem in English rather than in Latin. Our analysis shows him stepping away from a poetic and political tradition that saw AngloLatin verse as a medium through which public defenses of the English church could circulate, both within England and abroad. Engaged as it was in a different political project - one far more critical of the English church - Herbert's poem, we suggest, walked a narrow path, retaining and revising markers of the Neo-Latin brief epic while avoiding the political connotations the Latin language had for his generic predecessors.

\section{The Church Militant and the Neo-Latin Miniature Epic}

Herbert's poem narrates the history of the temporal church as a journey undertaken by an allegorical figure alternately called "Religion" and the "Church". It traces this figure's journey through its earliest iterations in Israel and Egypt, its later struggles in ancient Greece and Rome, its eventual transformation into modern Catholicism and Protestantism, and its subsequent flight westward, first to the New World, then west around the globe to Jerusalem at the end of time. ${ }^{2}$ At every stage, the Church is dogged by the allegorical figure of Sin, which consumes each of these religious institutions in turn; the poem's conclusion finds $S$ in in the process of corrupting the English church. This narrative arc has troubled readers - Herbert's contemporaries and subsequent generations of scholars - with its refusal to view the English church as the telos of ecclesiastical history. This section will place the poem within a Neo-Latin context, arguing that The Church Militant both adapted and undermined

2 All subsequent references to the English poem will appear in-text as line number references, and refer to the text in the Appendix to this article, taken from H. Wilcox (ed.), The English Poems of George Herbert (Cambridge, 2007), 664-684. 
the generic expectations of the Anglo-Latin brief epic or epyllion, a tradition with which Herbert had previously engaged in his poem Triumphus mortis (The Triumph of Death). ${ }^{3}$ Analyzing Herbert's engagement with, and rewriting of, this Anglo-Latin epic tradition serves to illustrate what motivated James Leeke's Latin translation and to explain the ways in which it alters Herbert's text.

Generically, The Church Militant is closely tied to the Neo-Latin brief epic, a widely practiced subgenre among English poets writing in Latin during the early decades of the seventeenth century. Estelle Haan has observed that, in contrast to "the undeniable dearth of full-scale [Neo-Latin] epic in England", the Elizabethan and Jacobean periods witnessed "the flourishing of a tradition of the brief epic", a "specifically Anglo-Latin genre" characterized by its "political and anti-Catholic subject matter". ${ }^{4}$ In the years following the 1605 Gunpowder Plot, "a virtual school of pseudo-Vergilian gunpowder epicists" emerged, producing over a dozen such works between 1605 and the mid-1620s. ${ }^{5}$ Positing an infernal origin story for the Gunpowder Plot's conspiracy allowed the authors of these works to emulate the structure of classical epics by alternating between human and supernatural theaters of action: Satanic forces, outraged at the strength of the English church, hatch a

\footnotetext{
${ }^{3}$ Following E. Haan and B. Lewalski, we will use the terms "brief epic", "miniature epic", and "short epic", and - for brevity's sake - "gunpowder epic" to refer to this group of works, though some scholars - among them Sutton, Applebaum, Poole and James prefer the term "epyllion". D. Sutton has rightly observed that these works are best considered as a genre in their own right: though "thoroughly unsatisfactory", perhaps, when read in terms of full-length narrative epics, they nevertheless conform to "an idiosyncratic genre which has its own conventions, raises different reader expectations, and deserves to be judged by different yardsticks.” See D.F. Sutton (ed., tr.), John Milton, In Quintum Novembris (Birmingham, 2013).

${ }^{4}$ E. Haan, "The British Isles", in S. Knight, S. Tilg (ed.), The Oxford Handbook of Neo-Latin (Oxford, 2015), 427-444 (at 436). For further discussion of the brief epic as a genre, see B. Lewalski, Milton's Brief Epic. The Genre, Meaning, and Art of Paradise Regained (London, 1968). As A. James notes, there was also gunpowder poetry written in English - including translations of poems originally in Latin and verse composed in English, and her book gives a thorough discussion of how the English genre's politics and forms differed. See A. James, Poets, Players, and Preachers. Remembering the Gunpowder Plot in Seventeenth-Century England (Toronto, 2016), 127-134.

${ }^{5}$ E. Haan (ed., tr.), Phineas Fletcher, Locustae, vel Pietas Jesuitica (Leuven, 1996), xxxiv. J.W. Binns catalogues sixteen such works in Intellectual Culture in Elizabethan and Jacobean England. The Latin Writings of the Age (Leeds, 1990), 457. Indeed, so pervasive was the influence of this genre that W. Hilton Killiher has remarked on the "epic fragments on the Gunpowder Plot that schoolboys and undergraduates were often set to compose during James's reign", in J.W. Binns (ed.), The Latin Poetry of English Poets (London, 1974), 44.
} 
Catholic plot within the human realm that divine intervention stymies. While conventions borrowed from Vergil and from Neo-Latin antecedents - notably Vida's Christiad (1535) - lent a lofty generic pedigree to certain aspects of the events described, the briefer length of these poems allowed their authors to introduce notes of mock-epic, satirical, or even salacious tones appropriate to topical commentary on current affairs. ${ }^{6}$ In their political content, these miniature epics celebrated "royal deliverance from Catholic conspiracy".7 They affirmed the efficacy of the English monarch in defending an English church caught, in the words of William Gager's gunpowder epic Pyramis (1608), between the twinned Scylla and Charybdis of popish and puritan excesses:

Hinc Romae, illinc insanimus amore Genevae, nil patrium nostrumque iuvat. Quod trans mare venit, hoc placet, hoc cordi est, sorcent nostratia nobis. In Scyllam laeva incidimus, dextraque Charybdim. (1014-1017)

Indeed, this metaphor was one Herbert himself had used in his earlier Latin poetry: De lupa lustri Vaticani (On the She-Wolf of the Vatican Brothel) mocks Puritans' "metus inanes" ("vain fears") of the Roman church, arguing that the "vulpem Britannicam" - the "British Fox", that is, British Puritanism - is as much a danger as the "Romanam Lupam" ("Roman Wolf"), and comparing these two factions to Scylla and Charybdis. ${ }^{9}$

\footnotetext{
${ }^{6}$ Haan 1996 (as in n. 5), xxx. As she puts it, "literati could implement the devices of epic and use its elevated language to parody the conspirators' failed attempt, while simultaneously heralding the kingship of James as a second Augustus", in Haan 1996 (as in n. 5), xxix. "Here was a theme," in Leicester Bradner's words, "which excited both horror and patriotism in the highest degree." See L. Bradner, Musae Anglicanae. A History of Anglo-Latin Poetry, 1500-1925 (New York, NY, 1940), 69.

${ }^{7}$ Haan 2015 (as in n. 4), 436. There were exceptions, as Jamie Reid-Baxter notes in his discussion of the Presbyterian poet Andrew Melville's Coniuratio pulverea: "[The poem] deals exclusively with the Plot as an 'instance of Catholic violentia' and with Rome's hatred of Protestant Britain, its king and his heir. [...] There is no encomium of James and no thanksgiving for his delivery, and, naturally, there is no hint at the anointed king's privileged relationship with the Almighty. Indeed, there is not the slightest hint that God intervened to foil the Plot." See J. Reid-Baxter, "Andrew Melville and the Gunpowder Plot, 1605-1609”, in R.A. Mason, S.J. Reid (ed.), Andrew Melville (1545-1622). Writings, Reception, and Reputation (London, 2016), 155-176 (at 167).

${ }^{8}$ D.F. Sutton (ed., tr.), William Gager, The Complete Works (Birmingham, 2017), at http://www.philological.bham.ac.uk/library.html. Sutton's translation: "On this side we are crazed with love for Rome, on that for Geneva. Nothing native and homegrown pleases us. Whatever comes across the sea delights us and is dear to our hearts. Whatever is ours displeases us. On the left we run into Scylla, on the right into Charybdis."
}

${ }^{9}$ J. Drury, V. Moul (ed.), George Herbert. The Complete Poetry (London, 2015), 240-241. 
Herbert's early Latin poem Inventa bellica (Warlike Inventions), in which he harnesses and ironizes formal elements of epic to sharpen antiCatholic satire, attests to his engagement with the gunpowder poetry of the 1600 s and $1610 \mathrm{~s} .{ }^{10}$ The poem traces humanity's coexistence with death, beginning with the earliest humans - who "quercus habitare feruntur" (5) - and chronicling the invention of increasingly sophisticated weaponry over the following millennia. Near the end of the poem, Herbert offers a mock-epic invocation to the Furies, whom he entreats to tell him the origin of the "monstrum" of gunpowder, recalling the "monstrum" often expelled from England in the gunpowder epic tradition. ${ }^{11}$ The resulting genealogy traces its lineage - at heroic length - from infernal ancestors to its most proximate parent, a monk,

$$
\text { qui limen opacae }
$$

triste colens cellae, noctuque et Daemone plenum, protulit horrendum hoc primus cum pulvere monstrum. (89b-91) ${ }^{12}$

The monastic cell, "noctuque et Daemone plenum" ("night and hellfilled"), recalls the subterranean antri in which the demonic casts of gunpowder epics plotted their interventions in human affairs. The lines that follow sharpen the satirical tone, suggesting that the monastic obsession with "mortem [...] et pulvere tristi" is, in Herbert's barb, appropriate to the inventor of this lethal technology (92-94). ${ }^{13}$ The poem's conclusion cements the link between Catholicism and warfare, introducing the figure of "omni / tormento peior Jesuita" and adding a reference to "sanguine regum" ("the blood of kings") that accentuates

${ }^{10}$ Later revised and retitled Triumphus mortis. V. Moul has noted the poem's connection to Neo-Latin gunpowder epyllia in Drury, Moul (as in n. 9), 528. To precisely date these poems is difficult. We accept the general consensus of 1618-1623. See Hovey 1981 (as in n. 1), 1-2. Kelliher has observed this connection, writing: "The heroic cast of the Latin verses is strengthened by the underworld setting which serves to swell them with classical names, while besides the moral disapproval thus conveyed the seeming grandeur of the surface is everywhere undermined by irony", in Binns 1974 (as in n. 5), 44.

${ }^{11}$ For "monstrum" see E. Haan (ed., tr.), Francis Herring, Pietas pontificia, in E. Haan, "Milton's In Quintum Novembris and the Anglo-Latin Gunpowder Epic", Humanistica Lovaniensia 41 (1992), 221-295 (at 223). Hovey's translation: "Men first dwelt in oaks, they say", in Hovey 1981 (as in n. 1), 301.

${ }^{12}$ Hovey's translation: "who in the sad / Dark threshold of his night and hell-filled cell / With powder first brought this dread monster forth", in Hovey 1981 (as in n. 1), 304.

${ }^{13}$ Hovey's translation: "night and hell-filled"; "Monks meditate on death and joyless dust - / Who would deny that they love lowly things / And, even more, what goes beneath the ground?", in Hovey 1981 (as in n. 1), 304. 
the connection that scholars - among them Hovey and Kelliher - have observed between Inventa bellica and the Gunpowder Plot. ${ }^{14}$

Herbert's Church Militant shares key structural features with both the gunpowder epic tradition and with Inventa bellica, his own entry in the Neo-Latin miniature- or mock-epic genre. As in a gunpowder epic, Church Militant draws its narrative propulsion from a "true" church under siege by infernal forces; like Inventa bellica, its trajectory stretches across millennia, beginning in ancient civilizations and following its central conflict through history to culminate in the present day - indeed, in the latter poem's case, projecting into the future. Beyond these structural similarities, Herbert adapts more specific tropes from the gunpowder tradition in the composition of Church Militant, most notably the scenes of impersonation in which Satan or one of his agents advances the conspiracy by adopting a disguise, whether that of a priest, a friar, a Jesuit, or, occasionally, a figure of female debauchery, like the character Aequivocus in Gager's Pyramis, whose opalescent, blended-fabric gown serves at once as disguise for her monstrous, Protean body and as quasiallegorical emblem of her duplicitous nature. ${ }^{15}$ Herbert draws on this trope of disguise during the repeated sequences in which Sinne adopts different forms to infiltrate the various churches that Religion has left behind. One such scene maps directly onto the gunpowder epic's characterization of Catholic figures as Satan in disguise: Herbert's Sinne

being not able to extirpate quite

the Churches here, bravely resolv'd one night

to be a Church-man too, and wear a mitre. (198-200)

These formal resemblances, however, only underscore how profoundly The Church Militant departs from the politics of the miniature epic tradition. Whereas gunpowder epics hinge on the successful repulsion of

\footnotetext{
${ }^{14}$ Hovey's translation: "the Jesuit, far worse than shot", in Hovey 1981 (as in n. 1), 304.

${ }^{15}$ E. Haan (ed., tr.), Michael Wallace, In serenissimi Regis Iacobi, in Ead., "Milton's In Quintum Novembris and the Anglo-Latin Gunpowder Epic. Part II", Humanistica Lovaniensia 42 (1993), 368-401 (at 378). For further commentary on the respective processional scenes involving friars, see Haan 1992 (as in n. 11), 237-239. Sutton 2017 (as in n. 8), 719-722: "E lino lanaque illi texta est toga, tota / versicolor, tenui ac subtili stamine, quali / non telam ipsa suam pertexit aranea, non sic / aut iris varia est, aut collum laeve columbi. / Non sua sic unquam Proteus mutaverit ora." Sutton's translation: "Her garment is woven out of linen and wool, completely parti-colored, made of a thin and subtle thread, such as no spider could use for its web. Neither the rainbow nor the opalescent neck of the dove is its equal. Proteus could not have thus changed his appearance."
} 
an external threat by England's pious monarch, Herbert's Church wanders "like a pilgrime, westward bent" (29), only pausing in England before continuing her journey across the Atlantic. By no means the island fortress whose ruler foils an attempted infiltration, England functions, in Herbert's poem, as little more than a waystation, one of many where the Church seeks temporary shelter in the course of a journey. Sin, in Herbert's poem, has successfully penetrated England's defenses on the heels of the true Church's departure: an ending that is a far cry from the triumphant repulsions with which earlier brief epics concluded.

Herbert's poem, then, declines to serve as a mouthpiece for a straightforward narrative of election or national foundation, thus resisting the narrative and political satisfactions of an epic tradition much older than the Neo-Latin gunpowder poetry of the early seventeenth century. In Herbert's poem, neither Sin nor Religion can find a permanent home: indeed, the poem's central argument is that true Religion has been - or will be - driven out of all historical religious institutions. Herbert's poem thus resists epic's "winner's history" structure, of which David Quint has penetratingly observed:

To the victors belongs epic, with its linear teleology. [...] Put another way, the victors experience history as a coherent, end-directed story told by their own power; the losers experience a contingency that they are powerless to shape to their own ends. ${ }^{16}$

Unlike Aeneas, whose wanderings give way to a story of national foundation, Herbert's ecclesiastical protagonist remains forever in motion, refusing to engage in a parallel act of patriotic teleology by settling in England.

The implications of The Church Militant's ending - which denied any special, elect status to the English church - troubled and upset Herbert's early readers, as three reactions to the poem in the year following its publication in 1633 make clear. The first was an attempt by an ecclesiastical censor, during the poem's printing, to strike the lines that most directly claimed that true religion was bound westward out of England. The second event was the citation of the same lines of the poem in the ecclesiastical trial of the minister Samuel Ward, a separatist accused of encouraging Puritans to migrate westward. The third was the rejection of these lines in letters between the eminent Cambridge theologian

${ }^{16}$ D. Quint, Epic and Empire (Princeton, NJ, 1993), 9. 
Joseph Mede and his friend William Twisse, who objected to the claim that religion was fleeing westward. These three events make clear that Herbert's contemporaries saw The Church Militant as aligned with the separatist, New World-bound Puritans who viewed the English church as hopelessly corrupt. ${ }^{17}$ These readings by Puritans did not, of course, acknowledge the larger structure of Herbert's poem, which predicts that Sin will eventually corrupt the American churches as well. In fact, the poem asserts the fallibility of all human religious institutions, in a manner somewhat reminiscent of Herbert's older brother's skepticism about institutional religion. ${ }^{18}$

The apparently anti-institutional tenor of The Church Militant is particularly surprising given the fact that Herbert's early poetry - much of it in Latin - engaged in religious polemic but advanced points of view that conformed to mainstream attitudes within the English church. These poems, mostly from the early 1620 s, include ingratiatingly anti-Catholic poems aimed at Elizabeth, Queen of Bohemia; anti-Puritan Latin verses that attack the minister Andrew Melville; a surprisingly moderate and perhaps even conciliatory Latin poetic exchange with Pope Urban VIII; and robust defenses of the English church's ceremonies and its investment in ecclesiastical hierarchy. ${ }^{19}$ One poem goes so far as to explicitly

\footnotetext{
${ }^{17}$ For these aspects of the poem's critical history, see Kuhn 2016 (as in n. 1), 69-72.

18 Our reading of the poem follows the general assessments of Fish and Shuger, who both see it as deeply, almost shockingly pessimistic about human religion. For Fish, the poem is "pessimistic, inconclusive, and anticlimactic"; for Shuger, the tone of the poem derives from the "austere and disillusioned apocalyptic determinism" of its source material, "the most depressing account of world history ever written". We thus sharply diverge from the handful of other scholars who have characterized the poem as either describing the "triumph of good" (Hovey) or as somehow maintaining a sense of the British church's elect status (Hodgkins). These readings (somewhat willfully) ignore the way that Herbert presents the English church as just one in a sequence of doomed institutions. See Fish, The Living Temple. George Herbert and Catechizing (Berkeley, CA, 1978), 144; Shuger 1997 (as in n. 1), 112; Hovey 1977 (as in n. 1), 48; Hodgkins, "Betwixt This World and That of Grace. George Herbert and the Church in Society", Studies in Philology 87.4 (1990), 456-476 (at 460-461). No one has significantly discussed, to our knowledge, the connection between this poem and Edward's philosophy, but they both share a deep sense of the eventual fallibility of all human religious institutions.

19 The poems to Elizabeth of Bohemia can be dated with some precision to 1622 . See T.-L. Pebworth, "George Herbert's Poems to the Queen of Bohemia. A Rediscovered Text and a New Edition”, English Literary Renaissance 9.1 (1979), 108-120. Melville's poems were written around 1603 but not printed until 1620. H. Wilcox, "Herbert, George (15931633), Church of England Clergyman and Poet", in the online Oxford Dictionary of National Biography (http://www.oxforddnb.com, henceforth ODNB), argues that Herbert's poems were written soon after Melville's poems were printed. The Urban
} 
claim that, in England, "nempe hic Religio floret" and that "tuque super nostras, Christe, moveris aquas." ${ }^{20}$ Collectively, these poems reveal a Herbert who, at the peak of his university career, supported mainstream Arminian or ceremonialist views, attacked Puritanism, and took varying stances on Catholicism depending on his audience and the immediate political context. This is not surprising, given the young Herbert's wellknown desire for ecclesiastical and political advancement, an aim these vigorous disputations on behalf of the English church might have been expected to further. ${ }^{21}$

The views voiced by much of Herbert's early poetry reflect those of the leadership of the deeply troubled late-Jacobean and early Caroline church. A group of bishops installed by Charles, most significantly William Laud - who would become Archbishop of Canterbury in 1633 led a controversial reform program during the 1620s and 1630s. These reformers, referred to by contemporaries as "Arminians", emphasized the importance of the church as an institution by enforcing ecclesiastical hierarchy, as well as by implementing "ceremonialist" practices that

poems must post-date 1623, when Urban became pope; given their attention to his choice of papal name, we suspect they were written in the immediate aftermath of his election. These poems, though they object to the Latin mass, avoid strident anti-Catholicism and even hint at the possibility of reconciliation between the two churches. This can probably be attributed to the fact that the early 1620s saw a thawing of official policy toward Catholic Europe and the increased toleration of English Catholics in the years before the failure of the Spanish Match. Indeed, Herbert himself had been directly involved in an attempt to warm relations between the Hapsburgs and England. Austrian and Spanish representatives visited Cambridge in 1622 - at the peak of negotiations surrounding the Spanish Match - to receive honorary MAs; Herbert, as University Orator, delivered a speech to mark the degrees' conferral. His remarks praised the Spanish Infanta, expressed delight at the visit of the "officers of the Catholic King", and trumpeted the success of Spain's imperial expansion to both the East and West Indies. For the only real scholarly treatment of these poems, see J. Doelman, "Herbert's Lucus and Pope Urban VIII", George Herbert Journal 32.1 (2008), 43-53. Herbert's oration is included among others in True Copies of all the Latine Orations Made and Pronounced at Cambridge (Cambridge, 1623). These poems, which appear variously in Lucus and Musae responsoriae, include both a generalized defense of the English church (In pacem Brittanicam) and also specific defenses of church ritual and ecclesiastical hierarchy. In these poems, Herbert defends the role of bishops (De praesulum fastu, De episcopis), the use of surplices (De superpelliceo), birettas (De pileo quadrato), church music (De musica sacra), and the use of rites generally (De rituum usu).

20 Drury, Moul 2015 (as in n. 9), 260-261. Moul's translation: "Surely Religion blossoms here, Queen of Peace, / And you, Christ, move upon our waters."

${ }^{21}$ Malcolmson 2005 (as in n. 1), 71-72, gives a good account of the gap between the public Herbert of the early 1620 s and the poem. Herbert's desire for political advancement appears to have waned by the late 1620s. See Wilcox in $O D N B$ (as in n. 19).

Humanistica Lovaniensia 67.2 (2018), 379-425 
augmented the centrality and splendor of church furniture, priestly vestments, and ritual action. For the so-called "Puritan" opponents of these practices, these reforms appeared suspiciously Catholic - if not actually pagan - and many responded by either fleeing to the New World during the "Great Migration" or generating the political resistance that would eventually trigger war a decade later. ${ }^{22}$ Most of Herbert's early public writings place him squarely in the Arminian wing of the church, whereas The Church Militant, as we have shown, took a strikingly different stance..$^{23}$

The poem's divergence from mainstream high church ecclesiastical politics helps to explain why - despite the religious subject matter and polemical tone of the poem, as well as its strong generic links to NeoLatin antecedents - Herbert did not compose the Church Militant in Latin. ${ }^{24}$ Examining Church Militant in conversation with the Neo-Latin poetic tradition it rewrote illuminates Herbert's bilingual poetic practice, revealing a poet who, in Latin, addressed himself to an international audience in defense of the English church and its changing stances, even as he employed English to express institutional skepticism and doubt. Furthermore, as the following section will show, it was precisely these controversial departures from Neo-Latin antecedents that James Leeke would, in translating Herbert, attempt to reverse, thus bringing the poem back into line with the institutional allegiances of the English church and the generic expectations of the Anglo-Latin epic tradition.

22 The classic account of these shifts in the church can be found in N. Tyacke, AntiCalvinists. The Rise of English Arminianism, c. 1590-1640 (Oxford, 1987).

${ }^{23}$ Writers from the seventeenth century onward have used a variety of terms for the group of ministers and bishops who championed ceremony and hierarchy in the English church during the 1620 s and 1630s. These terms include "ceremonialist" (which emphasizes the worship and ritual practices they implemented), "Laudian" (which emphasizes Laud's position as archbishop and advisor to Charles I and thus to some extent the political footprint of the group), and "Arminian" (which emphasizes the theological rationales behind their use of ceremony). We have chosen to use "ceremonialist" in this article given that James Leeke, Herbert's translator, focuses particularly on ritual. We reject "Anglican" as anachronistic.

${ }^{24}$ A Latin Church Militant, had it existed, could have been written in Latin initially or been issued as the kind of self-translation that bilingual authors often produced, as in the case of Hugo Grotius's Bewijs van den waren Godsdienst (1622) - republished in Latin for international circulation as De veritate religionis Christianae in 1627 - or Phineas Fletcher's gunpowder epic Locustae, vel Pietas Jesuitica (1627), which appeared simultaneously in an English edition in Spenserian verse. See P. Hardie, "Abraham Cowley, Davideis", in L.B.T. Houghton, G. Manuwald (ed.), Neo-Latin Poetry in the British Isles (London, 2012), 69-86 (at 71). 


\section{Leeke's Transformation of The Church Militant}

We have shown the ways in which The Church Militant resists the politics of Neo-Latin miniature epic even as it selectively borrows some formal elements from the genre, suggesting that the poem's controversial ecclesiastical politics - which are themselves intertwined with its narrative structure and generic source - may help to explain why Herbert wrote it in English. Looking at The Church Militant alongside another of its Neo-Latin contexts - a 1635 translation of the poem into Latin - will further illustrate Herbert's departure from the Neo-Latin poetic and political traditions to which his translator sought to return his poem. ${ }^{25}$ This translation, Ecclesia militans, sought to produce the Latin version of The Church Militant that Herbert himself seems deliberately to have resisted: the translator, James Leeke, makes additions and alterations that pull the poem nearer to the generic structures and political perspective of an earlier generation of Neo-Latin epics. Leeke's translation softens the poem's critiques of the English church, while amplifying its criticisms of other religious traditions, producing a version of Herbert's poem that would presumably have pleased the network of ceremonialist or Arminian ministers and politicians with whom Leeke was affiliated. Leeke's translation substantially revises Herbert's text, adding fifty lines of text and completely reworking some sections; this analysis will focus on those moments where the translation altered the political content of the poem most drastically.

Ecclesia militans survives in a unique manuscript copy at Durham Cathedral Library, ms. Hunter 27, at f. 190r-202r. ${ }^{26}$ It has never been

${ }^{25}$ All citations of the Latin text refer to the edition of Ecclesia militans that appears as an Appendix to this article.

${ }^{26}$ Ecclesia militans appears in a large folio volume in which the poem is bound with eighteen other miscellaneous texts of disparate origins. Ecclesia militans appears inside a small subgroup of bound items, alongside two other Latin texts, both in the same hand and on the same paper. The first is a dedicatory letter directed at Sir John Coke. The second is a Latin translation of the first stanzas of George Herbert's "Good Friday" that is short and hews very closely to the English original. The manuscript copy of the poem was acquired by Isaac Basire (1608-1676), as we know from his ownership mark on its final page. Basire was a French-born minister associated with Durham Cathedral in the mid- to late seventeenth century, who corresponded with James Leeke; letters between the two friends are also preserved elsewhere in the Hunter collection. After Basire's death in 1676, his papers were eventually absorbed into the library of Christopher Hunter (1675-1757), the collection's namesake, who bound them into larger volumes sometime in the late seventeenth or early eighteenth century. Hunter's library, in turn, passed into the Cathedral's hands upon his death in 1757 and its volumes have continuously remained there in the 
translated or given the thorough analysis it merits, and has almost entirely escaped scholarly accounts of George Herbert's poetry and its early reception. A.B. Grosart, in his 1874 edition of Herbert's works, provided a translation of the manuscript's prefatory letter to John Coke and reproduced around twenty lines of the Latin without translating it, dismissing the text as a curiosity. ${ }^{27}$ Another reference to the translation appeared in P.G. Stanwood's account of the poetry manuscripts held at Durham. Stanwood reprinted the first 65 lines of Leeke's Latin but did not provide a translation or commentary besides describing the translation as "efficient enough" but "having little gracefulness". ${ }^{28}$ Robert Ray noted the manuscript's existence in his survey of seventeenth-century allusions to Herbert's work but made no further comment. ${ }^{29}$ Other accounts of Herbert's early reception have mentioned Leeke only in passing - if at all - tending to focus on the later decades of the seventeenth century, as in Townend and Wilcox's work. ${ }^{30}$ To our knowledge, the only extant analytical treatment of Leeke remains a small section of Sebastian Köppl's 1978 German dissertation, which reprints passages accompanied by a few comments about Leeke's investment in the technique of amplificatio and which lacks detailed analysis or engagement with the translator's choices or biography. ${ }^{31}$

Why translate Herbert into Latin? The "chief aim" of Latin translations of English vernacular works, J.W. Binns has argued, "was to diffuse and disseminate the truth, in the most influential language [their translators] knew." 32 Latin renderings made these works accessible both

subsequent two and half centuries. See C. Brennen, "Basire, Isaac, de Preaumont (bap. $1608, d$. 1676)", in $O D N B$ (as in n. 19). Information about provenance is derived from P.G. Stanwood, "Poetry Manuscripts of the Seventeenth Century in the Durham Cathedral Library", Durham University Journal 62 (1969-1970), 88-90. Letters between Basire and Leeke can be found throughout Durham Cathedral Library, ms. Hunter 9.

27 A.B. Grosart, The Complete Works in Verse and Prose of George Herbert, vol. 2 (New York, NY, 1874), xxii.

${ }^{28}$ Stanwood 1969 (as in n. 26), 88-90.

29 R. Ray, "The Herbert Allusion Book. Allusions to George Herbert in the Seventeenth Century", Studies in Philology 83.4 (1986), 1-182 (at 9).

${ }^{30}$ H. Wilcox, "In The Temple Precincts. George Herbert and Seventeenth-Century Community Making", in R. Sell, A. Johnson (ed.), Writing and Religion in England, 1558-1689 (Farnham, 2009), 253-273; J. Townend, "Quantitative and Qualitative Approaches to Early-Modern Networks. The Case of George Herbert (1593-1633) and his Imitators", Literature Compass (2016), https://doi.org/10.1111/lic3.12374.

${ }^{31}$ S. Köppl, Die Rezeption George Herberts im 17. und 18. Jahrhundert (Heidelberg, 1978), 23-34.

${ }^{32}$ Binns 1990 (as in n. 5), 269. 
"to the scholarly continental public to whom English was a minor and unknown tongue, and secondly to those learned Englishmen who preferred to read works of their countrymen in Latin."33 Moreover, "translations from English into Latin in the Elizabethan and Jacobean period are mainly of theological works, and Latin is chosen as a medium of communication." 34 Beyond questions of transmission and readership, Victoria Moul has demonstrated that Latin translations of poetry could also function rhetorically, cementing a vernacular writer's place in an international and transhistorical canon still dominated by Latin works. ${ }^{35}$ Though "Latin translations of English poetry are not common" (Binns 1990, 251) in this period, those that existed help to explain the composition of Leeke's Ecclesia militans as both an expedient act for the young translator - who sought to advertise his credentials in pursuit of patronage - and as a service to the vernacular poet whose work, like that of Chaucer, Spenser, and Jonson, could now circulate abroad in a Latin version. $^{36}$ These aims - the legitimation of homegrown poets and the communication of religious arguments - come together in Leeke's Herbert, repackaged in Latin to champion English religion and poetry for an international audience.

Leeke's choice of Latin, however, cannot be read in isolation from the generic allegiances of his translation. The process of creating an epic Church Militant through translation entailed, for Leeke, Latinizing Herbert's text with additions and modifications that allude to classical epic, especially Vergil, and to the school of Anglo-Latin brief epic poetry that had flourished at Cambridge in the opening decades of the seventeenth century - itself, of course, indebted to Vergilian conventions. A characteristic example of Leeke's striking - even gratuitous insertion of epic elements comes early in the poem: Herbert's stark statement "spices come from the East" (13) expands, in Leeke's version, to "Orientem ut aromata Solem / agnoscunt genitorem, et odoribus ora

${ }^{33}$ Binns 1990 (as in n. 5), 241.

${ }^{34}$ Binns 1990 (as in n. 5), 268.

35 Of the several Latin translations of one Ben Jonson ode, Moul writes: "Responding to the vatic seriousness of Jonson's claims, these authors have used translation into (or almost, 'back' into) Latin to endorse his classical status in the strongest possible way." See V. Moul, Jonson, Horace, and the Classical Tradition (Cambridge, 2010), 203.

${ }^{36}$ W.L. Grant, "Vernacular Works in Latin Translation", Studies in the Renaissance 1 (1954), 124-126. 
Sabaeis / nostra beant, Tiphyn pressantia" (15-17). ${ }^{37}$ Ecclesia militans expands these lines by typically epic means, granting the "aromata" the capacity to recognize their semi-divine lineage in "genitorem", their odors the geographic specificity of "Sabaeis", and even a named captain to pilot them westward as cargo. With the latter addition, Leeke imports the character of Tiphys, and, with him, a rich history of classical and contemporary citation: the Argo's captain, beyond his inclusion in Apollonius of Rhodes's Argonautica, Vergil's Georgics, and Senecan tragedy, became an emblematic figure for exploration during the early modern period, and, more particularly, in the work of influential Anglo-Latin poets working within the brief epic genre. ${ }^{38}$ Leeke, for his part, presses the Argo's captain into service - for the transportation of spices, but also to initiate an elaborate simile, expanded from Herbert's perfunctory, almost implicit comparison - "thus" - to quasi-Homeric scale. Likewise, though Leeke uses the term "Solem" in this particular passage, Phoebus emerges throughout Ecclesia militans with roughly the same frequency as Herbert's "Sunne", overwriting the celestial star with a classical deity and nodding to epic - specifically Vergilian - conventions for marking the passage of time, as when Phoebus appears "Hesperiis festinans [...] in undis / tingere flammigerum caput" (42-43). ${ }^{39}$ This gesture was often emulated by gunpowder epicists, many of whom introduced periodic references to Phoebus's movements as markers for time's passage, or, occasionally, allowed him an enlarged role. In Michael Wallace's 1606 gunpowder epic, for instance, Phoebus's pallor serves as an omen of the conspiracy: "insueto vultus pallore nefandum / indicens facinus". ${ }^{40} \mathrm{In}$

37 "As spices recognize the eastern sun / as their sire and bless our mouths with Sabean perfumes, / freighting Tiphys."

${ }^{38}$ For more on the use of Tiphys as a figure for early modern explorers of the New World, see H. Hofmann, "Adveniat tandem Typhis qui detegat orbes. Columbus in NeoLatin Poetry (15th-18th Centuries)", in W. Haase, M. Reinhold (ed.), The Classical Tradition and the Americas (New York, NY, 1994), 420-656. Tiphys appears, for example, in Thomas Reid's Inventa adespota (96), which influenced, and circulated with, Herbert's Inventa bellica (Hovey 1981, 295), and in a 1633 poem, The Purple Island, by the gunpowder epicist Phineas Fletcher. See J.H. Pope (ed., tr.), Phineas Fletcher, The Purple Island. Or, The Island of Man (Leiden, 2017), 56.

39 "Rushing $[\ldots]$ to bathe his fiery head in Hesperidean waves." See, for instance, Verg. Aen. 11.896: "Ni roseus fessos iam gurgite Phoebus Hibero / tingat equos noctemque die labente reducat."

${ }^{40}$ Haan's translation: "giving clear indications of danger by his recent weakness." Wallace, 284-285, in Haan 1993 (as in n. 15), 384. See, for instance, Fletcher, 101, 161, 209-210, in Haan 1996 (as in n. 5), 8, 12, 14; or Herring, 4, in Haan 1992 (as in n. 11), 256. 
another gesture reminiscent of epic, Leeke tags many of his poem's characters with epithets that, while not repeated throughout the poem, nevertheless convey a sense of rich description in apposition with the names they modify: "diri Chami", "sedulus Ezra", "Moses signifer". 41 As these techniques suggest an epic influence on the translator's style and, more importantly, an epic vision for Herbert's poem - so Leeke's earlier correspondence with Isaac Basire, the manuscript's eventual owner, attests to his high regard for Homer's foundational place in the poetic tradition. A 1629 letter, with its suggestive mention of "Graeca carmina simul cum Latinis typis" ("Greek poems with, at the same time, Latin forms"), alludes to a lost painting by Galaton that depicts Homer vomiting a stream of poetic influence into the mouths of later writers. Leeke describes this process of literary transmission in terms at once intensely visceral and apparently appreciative, calling the stream of vomit "non esculanta vinum redolentia, sed aurea flumina" ("not edible morsels smelling of wine, but golden rivers"). ${ }^{42}$

In addition to his insertion of these epic conventions, Leeke transforms the parts of Herbert's poem that are most critical of the English church, turning Herbert's blunt narratorial claims about the failures of the Reformation into opinions bounded by the perspectives of the characters who hold them. This shift is particularly striking in Leeke's revision of a moment in which Herbert predicts that the postReformation Protestant church will "decline and fade", unable to recreate the purity of earlier times. In Herbert's original,

The second Temple could not reach the first:

and the late reformation never durst

compare with ancient times and purer yeares;

but in the Jews and us deserveth tears. (245-249)

Leeke's translation radically alters this section, rendering it as:

Ac veluti memorans Salomonica templa, nitorem haud restituens similem reparandis, sedulus Ezra

conditor erubuit, pudibunde conscius: horret

41 "Ill-omened Ham", "industrious Ezra", and "sign-bearing Moses", respectively.

${ }^{42}$ James Leeke to Isaac Basire, 1629. Found in Durham Cathedral Library, ms. Hunter 9, f. 1r. While another letter from Leeke to Basire was transcribed and translated in the mid-nineteenth century as part of a biography of Basire, this letter, containing a long discussion of aesthetics and rhetoric, was not included. See W.N. Darnell, The Correspondence of Isaac Basire, D.D. (London, 1831). 
sic tot ruderibus renovata Ecclesia abactis

nupera, componens annis sua tempora priscis;

concipit Hebraei hinc mens ambitiosa dolorem,

cogit et hoc oculis lachrumarum flumina nostris. $(269-275)^{43}$

Leeke reseats Herbert's magisterial assertion that "the second Temple could not reach the first" in the consciousness of the architect Ezra ("sedulus Ezra / conditor"). Instead of an ostensibly objective narratorial statement about the second Temple's failure, Leeke presents Ezra's emotional response to this thought ("erubuit, pudibunde conscius"), itself based in personal recollection ("memorans") of the first - here, "Salomonica" - Temple. Indeed, Leeke depicts Ezra's emotional response as physically symptomatic, the latter's memory of the earlier temple manifesting itself as a visible blush. Leeke links this sorrowful Ezra to a personified and feminine Protestant church who "componens" as Ezra once did and "horret" as he once "erubuit". The Protestant church, which these lines in Leeke personify as Herbert did not, shudders because she believes, like Ezra, that she cannot repair herself sufficiently; these expressions of personal - and personified - regret differ sharply from Herbert's flat, evaluative statement that "the second Temple could not reach the first" and "the late reformation never durst compare" with ancient times. Leeke's translation, then, presents Herbert's statement about the decay of the English church not as a simple prophetic truth, but as a viewpoint mediated through the poem's characters.

Leeke also mitigates Herbert's doubts about the permanence of the English church in his handling of the poem's most famously controversial lines - the lines that attracted the attention of a contemporary ecclesiastical censor - which predict that "Religion stands on tip-toe in our land, / Readie to passe to the American strand" (258-259). Herbert's statement renders the flight of religion out of England with prophetic certainty, its tone audible to the poet's near contemporaries: Cotton Mather would reprint these lines as an epigram to a sermon later in the

43 "But just as, remembering the Salomonic temples, hardly / restoring a brightness like that of renewal, industrious Ezra / the builder blushed, shame-facedly aware: so too the late Church, renovated by so many removed rubbishes, / shudders, building her own ages from ancient years: / hence, the ambitious mind conceives of the sadness of the Hebrew, / and this drives rivers of tears from our eyes." 
century, titling them "A Prophecy in the Divine Herbert's Church Militant". ${ }^{44}$ Leeke's Latin softens this "prophecy" considerably:

Sentitur Pietatis apex: alata supremo ungue premit nostram hanc tellurem, ad America vergens littora. $(283-285 a)^{45}$

While it retains the image - down to the "supremo / ungue" on which religion stands poised - Leeke's translation makes one crucial alteration, framing Herbert's declarative statement with "sentitur". This choice related to, but more muted than, the attribution of opinions to named characters, as in the Ezra passage - portrays the statement that follows as a generalized, impersonal viewpoint that is "perceived" or "felt", a perception rather than a prophetic inevitability. This alteration, though subtle, softens Herbert's most aggressive and contemporarily controversial attack on the English church.

As Leeke's poem mitigates Herbert's critique of the English church, he also heightens the English poem's satire of the Catholic church. ${ }^{46}$ Though Herbert's poem does contain anti-Catholic material, Leeke's translation, as part of its larger project of generic revanchism, vastly amplifies the scale and savagery of its satire. Herbert's poem portrays a masculine Sinne who,

not being able to extirpate quite

the Churches here, bravely resolv'd one night

to be a Church-man too, and wear a Mitre. (161-163)

With "Church-man", the poet reminds us that Sinne's gender allows him to assimilate seamlessly into the higher ranks of Catholic hierarchy, donning his "Mitre" for this masquerade. Leeke dramatically transforms these lines, presenting the reader with a feminine Sin:

\section{furibunda virago}

nocte novum facinus versabat; nempe vicissim sacricolam simulare, sacram ostentando tiaram. Proh scelus! Impostrix, lena execranda, putari gestiit Expositrix rerum importuna Sacrarum.

${ }^{44}$ Cotton Mather, The Wonderful Works of God (Boston, 1690), 63.

45 "The height of piety, it is felt: winged, she presses / into our earth, on highest toe, inclining toward American / shores."

${ }^{46} \mathrm{Köppl}$ (as in n. 31), 30-31, very briefly notes that the translation is comparatively anti-Catholic, but his account does not provide any detailed analysis or comparison. 
Traiiciens oculum per scissa foramina, vidi musaeolo intentam libris, discrimina oborta volventem; Calamus decuit Pecus, Ausoniaeque dona severa togae; constantis gratia vultus non Erebo, at caelis oriundos prodidit ignes. $(201 \mathrm{~b}-210)^{47}$

Though Leeke often renders Herbert's "Sinne" as "Impietas", a feminine noun, here, he genders and embodies the character much more forcefully, in part by placing her in apposition to a series of feminized coinages and unusual nouns that draw on contemporary satires of the Catholic church as the Whore of Babylon. ${ }^{48}$ Leeke's Sin becomes, in quick succession, a "furibunda virago", a "lena execranda", an "Impostrix", an "Expositrix": conqueress, procuress, impostress, expoundress. Each label shows her capable of, and culpable for, a different transgressive form, whether appropriations of traditionally masculine endeavors - military conquest, scholarly exposition - or enactments of supposedly feminine faults - seduction, deceit. Herbert's lines stress the ease with which Sin, as a "Church-man", impersonates a scholar, yet the same actions become doubly subversive when Leeke's embodied, feminized Sin acts as the "Impostrix". 49

As with his treatment of Catholicism, Leeke heightens Herbert's satire of other religions, using scatological and grotesque imagery to introduce a sense of visceral disgust characteristic of the gunpowder epic's strain of satire. In The Church Militant, Herbert's Sin "did sow / gardens of gods, which ev'ry yeare did grow / fresh and fine deities" (107-109). In place of Herbert's "gardens of gods" with their "fresh and fine" flora, Leeke's version presents a soil-level view of the symbiosis between divine "semine [...] gramineo" and a fertilizing cow:

47 "The frenzied she-warrior / was hatching a new crime by night, surely to impersonate / a worshipper once again by displaying a holy headdress. / Alas, crime! The Impostress, detestable bawd, delighted to be considered / a troublesome Expoundress of sacred things. / Casting my eye through torn peep-holes, I saw / her engrossed in books in a study, mulling over recent distinctions; / a reed pen suited the Beast, and the severe gifts / of an Ausonian toga; the grace of the faithful expression / suggested fires born not in Erebus but the heavens."

${ }^{48}$ For more on the use of feminized figures as fodder for anti-Catholic satire in the gunpowder epic tradition, see James 2016 (as in n. 4), 134-137.

49 Sin's gender similarly inflects Leeke's later insistence that "non hastas, non ferra vibrant, non tympana pulsant / victricesque comant linguarum murmure terras" (243-244), where the substitution of verbal persuasion ("linguarum murmure") for military force draws on gendered assumptions about gossip and physical combat. 
Occupat ut Memphin, veneranda ibi semine spargit

Numina gramineo; rediere haec sparsa quotannis

foeta, faceta, pium magno bovis excremento

foecundante solum. Oh, bis prodigus iste, voraces

cui subit a Divo cohibere legumine dentes! (138-142) 50

Here, Leeke dwells on the bodily processes that render a cow "bis prodigus", narrating the digestive process by which its "voraces dentes" transform a "Divum legumen" into the "magno bovis excremento". ${ }^{51}$ Leeke, in other words, creates an association between ruminant digestion indeed, fecal matter - and Egyptian religious practices, encouraging his reader to view the latter with alienation and disgust. Intriguingly, Leeke's image mirrors one used by the gunpowder epicist Michael Wallace, who compares Jesuit teachings to "ore eiecta feri foeda excrementa draconis". ${ }^{2}$ Leeke uses a similar technique in his discussion of Islam, which he construes as a monstrous and menacing affront to Christianity. Where Herbert condescendingly dismisses "such Mahometan stupidities / as the old heathen would deem prodigies" (153-154), Leeke recasts Islam in far more threatening terms:

Improba at horum

pectora luxurians magicarum inventio rerum

prodidit, Antichristicolarum admittere cultus

horribiles, veterumque fidem superantia monstra. (190b-193) $)^{53}$

50 "As it occupies Memphis, there it strews the venerable deities / in grassy seed; these sprinklings yearly returned, / fertile, cultivated, to the pious ground as the great, fertilizing / excrement of a cow. Oh, that twice-prodigious one, whose / voracious teeth it tries to restrain from the divine legume!"

${ }^{51}$ This image recalls the scatology of Hor. Epod. 8.5-6.

52 "Tunc in canitiem nigranti vertice verso / protinus unius faciem vultumque cohortis / infaustae primam quam concidit ignis et Ate / ore eiecta feri foeda excrementa draconis, / mentito quae nomen habent a nomine Iesu, / induitur, longaeque incedens syrmate abollae / vestigat sceleri tanto quem destinet aptum". Michael Wallace, 157-163, in Haan 1993 (as in n. 15), 378. Haan's translation: "Then immediately turning his black head into white, he assumed the appearance and countenance of one of the ill-omened body which was originally founded by fire and Rashness, belching foul excrement from the mouth of a fierce dragon, and which is falsely named after Jesus, and advancing in a long cloaked habit, he tracks down one whom he may appoint as suitable for a crime", in Haan 1993 (as in n. 15), 379.

53 "Yet the abundant ingenuity / of magical things allowed their wicked hearts to accept the horrible cults / of the Antichrist-worshippers, and the old ones' faith [to accept] abounding monsters." 
Leeke's choice of the unusual term "Antichristicolarum" construes Islamic practices as a direct affront to, or negation of, Christian beliefs, even as it echoes the "Christicolae" celebrated by the gunpowder epic tradition. ${ }^{54}$ Similarly, his use of "monstra" here recalls his earlier claim of baptism's ability "de rabidis generare potissima monstris" ("to beget supreme results from raving monsters", 64) in reference to Pharaonic Egypt, the shared vocabulary proposing an unflattering continuity between contemporary Islamic practices and Egypt's animistic past. In constructing this passage, Leeke draws not just on the broad tropes of the gunpowder epic tradition - and on their paranoid fear of religious and cultural difference - but on the specific Latin vocabulary used to evoke the sense of disgust that characterized the genre, particularly monstrum and forms of the verb horrere. ${ }^{55}$ The latter occurs both frequently and prominently in several gunpowder epics - appearing, for instance, in their opening lines - as a "monstrum horrendum" in Herring's Pietas pontificia, verse 9, and a "concilium horrendum" in Fletcher's Locustae, verse 7 - where it plays a central role in establishing the tone of these poems and guiding their readers' engagement with the events they describe. Leeke's reference in these lines to "cultus horribiles" recalls these "horrendum" agents and underscores the frequency of horrere and its forms, which recur nine times in Ecclesia militans.

These changes, taken collectively, transform Herbert's poem into a more conventional polemic, shifting the balance of satire away from the English church and toward other religions. From this analysis, Leeke's sharpened satire appears not to offer a positive vision of, or for, the English church amid its attacks on other religions and cultures. However, a sense of Leeke's sectarian investments inheres in his translation of Herbert's section on contemporary Catholicism. In Herbert's poem, Sin resolves "to be a Church-man too, and wear a Mitre" - a bishop's headdress often targeted in Puritan attacks on ceremonialist emphasis on ritual garb and hierarchy. Leeke's translation distances this phase of Sin's journey from English ceremonialism, shifting the grounds of this attack to Catholicism and rendering the headdress in question as a

${ }^{54}$ A compound of "Antichrist" and the suffix -cola ("worshiper, believer, adherent"). For Christicolae, see, for instance, Fletcher, Locustae, 254, in Haan 1996 (as in n. 5), 16.

${ }^{55}$ Haan, in her work on gunpowder epics, has observed the centrality to the genre of both "the summoning of a monstrum and its subsequent flight" and narratorial attempts to convey "horror at the barbarity of the plot", in Haan 1992 (as in n. 11), 225. 
vaguer "tiaram". In these lines, Leeke stresses the figure's connection to ancient, pagan Rome - rather than contemporary Catholic practices - by equipping her with a "Calamus", or reed pen, and an "Ausonian toga". Where the "Mitre" of Herbert's "Church-man" situates Sin precisely within the contemporary ecclesiastical hierarchies that Puritans so detested, Leeke's "sacricolam" - roughly, "worshipper" or "sacrifice officiant" - assigns his feminized Sin a much more ambiguous position in the church she infiltrates. In the works of Roman historians, the term sacricolae refers, specifically, to the temple devotees among whom a visitor disguises himself; here, Leeke's use of the same word breaks Herbert's satirical link between Sin and the ceremonial and hierarchical aspects of worship beloved by Catholics and English ceremonialists alike, and, in doing, reframes Herbert's satire in a form more acceptable to an ceremonialist or Arminian audience.

Leeke's changes to Herbert's poem reflect the broader political and ecclesiastical circles in which the translator seems to have moved in the mid-1630s. A skeletal outline of Leeke's life can be reassembled from scattered archival documents: a process made more complicated by the profusion of possible spellings of his last name. Born in Balderton, Nottinghamshire, in 1605, Leeke matriculated at Pembroke College, Cambridge, as a sizar in 1623, a position that suggests he was from a middling or lower-class background. ${ }^{56}$ Leeke shifted to Peterhouse in

${ }^{56}$ Note: the translator James Leeke is not to be confused with a different James Leeke, also from Nottinghamshire, who was a schoolmaster in Nottingham and, in January 1647, accidentally struck and killed a man named Bevill Verye with his carriage. The two James Leekes both died in the mid-1650s, were both highly educated, and were from towns only roughly twenty miles apart. For the schoolmaster / murderer James Leeke, see Records of the Borough of Nottingham, vol. 4, 1625-1702 (Nottingham, 1900): Leeke's appointment as schoolmaster, 131; carriage accident, 248. Details of the translator James's branch of the Leeke family can be found in the group of pedigrees collected by William Dugdale during his visitation of Nottinghamshire in 1662. These are reprinted in G.B. Squibb (ed.), The Visitation of Nottinghamshire Begun in 1662 and Finished in 1664 (Florence, 1986), 47. Two notes: James's death date appears to be in error in this edition, reading 1644 instead of 1654 (the year his will, preserved in the Prerogative Court of Canterbury, was proved). It should also be noted that the Dugdale pedigree claims James's brother Francis Leeke was High Sheriff of Nottingham in 1660; this appears to be an error for a different Francis Leeke, first Earl of Scarsdale, known for apprehending Colonel Hutchinson at the end of the English Civil War. For details of the first Earl of Scarsdale's life, which demonstrate he could not be related to the translator's family, see G.E. Cokayne (ed.), Complete Baronetage, English, Scottish, and Irish, vol. 3, 1649-1664 (Exeter, 1903), 285-286. The authors have not had a chance to consult the original Dugdale manuscript collection at the College of Heralds, and so it is unclear whether these errors are Dugdale's or his later editors'. 
1626, where he received his BA, MA, and BD between 1627 and 1637.57 Two letters survive relating to his elevation to fellow in 1628 , one discussed above - from Leeke's father on 1 July to John Coke, junior Secretary of State, then sitting as MP for Cambridge, and a second from the senior Secretary of State, Edward Conway, to the master of Peterhouse on Leeke's behalf on 15 July. ${ }^{58}$ It seems likely that Conway may have stepped in as recommender, since Coke had been dispatched to Portsmouth in mid-May 1628 to supervise naval preparations and would not return until later in the year. ${ }^{59}$ During this time, as many scholars at Cambridge did, Leeke produced commendatory Latin poetry for the royal family, contributing verses to two collections produced by Cambridge for the births of James II (1633) and Anne (1637). ${ }^{60}$ If Leeke produced texts beyond his Herbert translations and this commendatory verse, they are lost to us - though, tantalizingly, his will bequeathed to his nephew "all my paper books Latin or English in verse or prose whether of my own labor and invention or of others". ${ }^{61}$

No direct evidence of Leeke's religious and political beliefs exists, but his allegiances can be inferred to some extent from the networks and institutions to which he belonged. These placed him in close contact with the ceremonialist wing of the English church during the movement's ascendance in the 1630s. Leeke was a Fellow of Peterhouse College at Cambridge after 1628, at which time the college was notoriously Arminian. John Cosin, one of the most well-known and controversial Laudian ministers in the nation, was Master of the College from 1634, after a stint as Bishop of Durham. At both institutions Cosin implemented ceremonialist worship practices: the complaint against his

57 These details are gleaned from the entry for James "Leke" in J. Venn (ed.), Alumni Cantabrigienses. A Biographical List of All Known Students, Graduates and Holders of Office at the University of Cambridge, from the Earliest Times to 1900, vol. 1 (Cambridge, 2011), 59.

58 The letter from James Leeke Senior can be found in The Manuscripts of the Earl Cowper, KG, Preserved at Melbourne Hall, Derbyshire, vol. 1 (London, 1888), 357. For the letter, two weeks later, from Conway to Cambridge, see London, The National Archives, State Papers, series 16, box 110, 25.

${ }^{59}$ M.B. Young, "Coke, Sir John (1563-1644)", in $O D N B$ (as in n. 19).

${ }^{60}$ Ducis Eboracensis Fasciae a Musis Cantabrigiensibus raptim contextae (Cambridge, 1663); and Synoidia, sive Musarum Cantabrigiensium concentus et congratulatio, ad serenissimum Britanniarum Regem Carolum, de quinta sua sobole, clarissima principe, sibi nuper felicissime nata (Cambridge, 1637).

${ }^{61}$ London, The National Archives, Prerogative Court of Canterbury, series 11, box 241,460 . 
activities at Durham by Peter Smart, which needs to be read in its entirety to be fully appreciated, spends twenty-eight folio pages narrating Cosin's ceremonial excesses in matters ranging from candles to vestments to music to church decoration. ${ }^{62}$ During the period of his fellowship at Cambridge, Leeke was a minister in two locations near Cambridge: first at Impington from 1631-1632 and then at Little Saint Mary's (also known as Saint-Mary's-the-Less) from 1632-1636. ${ }^{63} \mathrm{He}$ would be replaced in 1636 at Saint Mary's by Richard Crashaw, a fellow student at Peterhouse who was notoriously invested in ceremonialism. ${ }^{64}$ Leeke's occupation of these Peterhouse-controlled benefices in the mid1630s may be further evidence of his ceremonialist affiliations.

Further tentative evidence for Leeke's affiliation with ceremonialist interests can be seen in his involvement in an unusual and complicated lawsuit in 1639, four years after he produced Ecclesia militans. The lawsuit, a dispute over a ministerial living in Hockerton, Nottingham, only a few miles away from Leeke's hometown Balderton, pitted the chancellor and scholars of Cambridge against a Catholic recusant named John Moore, who sought to prevent Leeke's appointment. It is possible that this was merely motivated by local grievances, given Hockerton's proximity to Balderton and to Halam - a mere three miles away - where another branch of the Leeke family owned significant property. ${ }^{65}$

62 The charges are reprinted in full in The Correspondence of John Cosin, D.D., Lord Bishop of Durham. Together with Other Papers Illustrative of His Life and Times, Part I (Durham, 1869), 161-199. A brief snippet will serve to give a sense of the tone of the complaint. "Which your elder brother, and a senior residentiary, Peter Smart seing, and perceiving the simple people inveigled and beguiled, by your popish baits and allurments of glorious pictures, and Babalonish vesturs, and excessive number of wax candles burning at one tyme, and especially the horrible profanation of both the sacraments with all manner of musick both instrumentall, and vocall, so lowde that the Ministers could not be heard, what they said, as if Bacchanalia, the feasts of Bacchus, or the Aegiptian Isis, or the Phrygian Cybele [...] with fluits and bag pipes with tymbrells and tabers and not the Death and Passion of our Saviour Christ were celebrated moreover seing the poore people of Durham miserably misled by the hypocritical seeming holynes of you all especially you Cosin in upstartings, downe-squattings, east-turnings, crossings and kissings altarclothes, and the elements of bread and wine with your frequent and profound duckings and prostrations before your most sumpteous Altar all which your abominations both towne and country began to imytate to the shame of our church."

${ }^{63}$ Details of Leeke's Cambridge career can be found in Venn 2011 (as in n. 57), 59.

64 T. Healy, "Crashaw, Richard (1612/13-1648), Poet", in ODNB (as in n. 19).

65 Robert Thoroton, The Antiquities of Nottinghamshire (London, 1677), 320. Thoroton's text contains details about one branch of the Leeke family owning property in Halam and also gives a skeletal family tree of heirs that includes Jacob Leeke of Balderton and Francis Leeke of Balderton, James's father and older brother, respectively. 
Aspects of the complaint, however, suggest that the lawsuit may have been related to fear of ceremonialist innovations in Nottingham. Moore, as his answer to Cambridge's complaint indicates, was worried that "some others were about to purchase the said Advowson whom this defendant was not willinge should have any thing to intermedlle in the said Manor or parish." Of his purchase, Moore continues, the

fiftie pounds aforesaid this defendant was willinge to give to purchase peace and prevent such other purchasers as intended to purchase the said Advowson which this defendant feared might have been troublesome in the said parrish. ${ }^{66}$

Moore declines to specify what form he feared the "intermeddling" or "troublesome" activity might take, though Leeke's associations - including the support he received from the Chancellor of Cambridge, who was, in 1639, the ceremonialist John Cosin, formerly Master of Peterhouse raise the possibility that Moore may have had in mind the kinds of highchurch innovations that had been taking place elsewhere in the nation. Moore's attempt to block Leeke's appointment was also resisted by the Archbishop of York, Richard Neile, who attempted to delay the preemptive appointment made by Moore. ${ }^{67}$ Neile was another noted ceremonialist closely connected to Cosin, whom he had employed as domestic chaplain earlier in his career, and both men - along with other figures associated with Durham and Peterhouse - had been part of the strongly ceremonialist Durham House group in the 1610s and 1620s. ${ }^{68}$ Their involvement in this lawsuit shows that Leeke continued to benefit from the patronage of powerful Arminian figures in the late 1630s.

Leeke's connection to these figures is further borne out by the manuscript's eventual owner: on its final page, the text bears the ownership mark of Isaac Basire, a French-born minister and intellectual with connections to ceremonialist figures. Basire had been Thomas Morton's personal chaplain from 1629 onward, after Morton replaced Cosin as Bishop of Durham. Basire spent several months at Cambridge in 1635,

\footnotetext{
${ }^{66}$ Moore's answer appears as the third document in Cambridge University vs. Moore, held at the British National Archives, C 8/78/58.

${ }^{67}$ As indicated in the proceedings of Cambridge University vs. Moore, Moore filed a writ of quare impedit versus the Archbishop, a specialized legal proceeding designed to protest an archbishop delaying or refusing an appointment made by a patron. Thanks are due to Andrew Foster for some personal correspondence that helped to clarify this lawsuit.

${ }^{68}$ See A. Foster, "Neile, Richard (1562-1640)", in $O D N B$ (as in n. 19).
} 
at which time he likely acquired the manuscript, though his correspondence with Leeke began at least as early as 1629 . This provenance, read alongside other available evidence about Leeke's life, suggests that we should understand Ecclesia militans as the work of a junior member of the Durham-Cambridge ceremonialist axis during the peak of its influence in the 1630 s.

Leeke's attempt to blunt the satire of the English church and remove references that might seem to criticize a ceremonialist position makes sense given his affiliations, but his background alone does not fully explain the translation's considerable amplification of anti-Catholic satire, especially given the links, both real and imagined, between some Arminian or ceremonialist figures and Rome. ${ }^{69}$ The fervid antiCatholicism of the translation can be explained, perhaps, by the translation's dedicatee, John Coke, Charles's Secretary of State, to whom Leeke fulsomely inscribed his text in January 1635. James Leeke Sr. the translator's father - had written Coke to ask for his support of James Jr.'s elevation to fellow at Cambridge in 1628, an act which indicates some personal connection between the families. Somewhat irritatingly, despite the translation's fulsome dedicatory epistle to Coke, we have not found concrete evidence that Coke received a copy, and no letter from the younger Leeke appears in the surviving Coke correspondence. ${ }^{70}$ Ecclesia militans does, however, appear consistent with Coke's politics in the mid-1630s. Coke's own position on the domestic religious controversies of the 1620s and 1630s is obscure, but he was a well-known opponent of Catholicism and seems to have broadly disliked challenges to the church's authority. During the mid-1630s, Coke's antiCatholicism led to his membership in a high-profile anti-Spanish faction at court: for example, in 1635 - the year of Leeke's translation - he

${ }^{69}$ The relationship between English Arminianism and Catholicism in the Caroline era was immensely complicated. Many Puritans accused Arminians of secretly conspiring with the papal Antichrist. In practice, however, these figures had a wide array of feelings about Catholicism: some eventually left the English church for Catholicism, some actively sought reconciliation between the churches, and some feared and loathed Rome. For a survey of this history, see M. Questier's helpful account in "Arminianism, Catholicism, and Puritanism in England during the 1630s", The Historical Journal 49.1 (2006), 53-59.

70 The absence of a Leeke manuscript in the Coke papers does not mean Coke did not receive it; another Latin manuscript Coke received during this period (Bolton's life of Tiberius) was sold to an Italian collector in 1801, evidence perhaps that Coke's collection may have fragmented in subsequent centuries before it was fully calendared in 1888. For the fate of the Bolton manuscript, see I manoscritti della raccolta Durazzo (Genova, 1979), 118. Thanks are due to O. Holmes for an on-the-fly translation of this entry into English. 
attempted to suppress the Catholic chapel operating in the ambassador's house in London. ${ }^{71}$ Earlier in Coke's career, when asked to weigh in on the creation of a history lectureship at Cambridge, he stated that the work of a historian was to combat the popish "adversaries" and "discover their ambition, covetousness, impostures, tyrannies, treacheries, and all the depths of hell in that Roman gulf": given this, one can assume he would be receptive to the changes made to this poem by Leeke, a fellow Cantabrigian. The biographer Michael Young has suggested that the elderly Coke's anti-Catholicism was a holdover from his youth in the Elizabethan and early Jacobean eras, when he served under more aggressively anti-Catholic and anti-Spanish political regimes. ${ }^{72}$ We would even suggest that the translator Leeke may have turned to the formal and political idiom of the gunpowder mini-epic - a genre that was quite belated by the 1630 s - to specifically target the elderly patron's nostalgia for an earlier era's more Catholophobic politics and the poetic form in which they were most aggressively expressed. In any case, Leeke's translation, which mutes the Puritanadjacent notes of anti-ceremonial polemic present in the original text while heightening its anti-Catholic satire, seems perfectly calibrated to please a patron in the mainstream of the English church with a particular dislike for Rome. Indeed, the larger narrative of European decay presented by Herbert's text - and amplified in Leeke's translation resonates with Coke's own remarks, just a year later, at Oxford, which present a bleak picture of a once-strong Europe devastated by war and confessional struggle. ${ }^{73}$

71 For Coke's general anti-Spanish and anti-Catholic attitudes, see M.B. Young, Servility and Service. The Life and Work of Sir John Coke (Dover, NH, 1986), 231; and A.J. Loomie, "London's Spanish Chapel Before and After the Civil War", British Catholic History 18.4 (1987), 402-417 (at 406).

72 Quoted in Young 1986 (as in n. 71), 37-38.

73 "I have seen our neighboring countries in great prosperity and renown, their cities stately built and strongly fortified, with walls raised up to heaven, full of people, full of trade, so full of peace and plenty, that they surfeited in all excess; but from hence they are since fallen, partly by the boundless ambition of great princes, partly by the factions and divisions in religion, and generally by their disorders, into such condition, that men of great honor sent in remote employment, found whole provinces so sacked and depopulated, that in divers journeys they encountered scarce a man, and those they found dead, some had grass in their mouths and stomachs, and some were torn in pieces by beasts and ravenous fowls, and those that were alive had no other care or study than how to save themselves from fire and sword. In general there is such desolation, that without a kind of horror, the horror thereof cannot be expressed." Coke's address to Oxford is reprinted in full in J.H. Parker (ed.), The Works of Archbishop Laud, vol. 5.2 (Oxford, 1853), 131. It is 
Leeke's transformation of the poem, beyond affirming Coke's political and religious views, also raises important questions about the broader audience of Ecclesia militans and its potential for international circulation in print. His choice of Coke as a dedicatee speaks to the possibility that Leeke sought print sponsorship for his translation. Coke was, in 1635, in the process of paying for the printing of another Latin work by an English author, John Selden's Mare clausum. Coke sponsored Selden's text - which made the legal case that nations could claim maritime territory in the same manner as land - as part of a larger political push to combat French, Dutch, and Spanish fishing and piracy by asserting English control over neighboring waters. ${ }^{74}$ Leeke, in courting Coke as a patron, may have envisioned international circulation for his text and coveted the kinds of sponsorship the nationalist and antiCatholic Coke offered in the mid-1630s.

Understanding Leeke's Church Militant in this way - as a text produced within a network of thinkers invested in the institutional and ceremonial forms of the English church - brings the translation's departures from Herbert's source text into sharper focus. Leeke's translation, as we have shown, amplifies Herbert's satire of other religions, softens Herbert's claims about the English church's decay, and quiets the poem's disinvestment in the world's temporal churches. Ecclesia militans, stripped of the full force of Herbert's most critical claims about English religion, reflects the political and religious commitments of a translator who sought the broader - perhaps international - circulation of Herbert's poem, the patronage of the anti-Catholic and nationalist Coke, and the continued support of Basire and others within the extended Peterhouse-Durham network. Our reading, then, places Leeke at the beginning of a reception history that has long strained, editorially

worth noting that 1635 was something of an inflection point in the relationship between England and Catholic Spain; after the death of Thomas Wentworth, the major hispanophilic voice at court, Laud and Coke succeeded in steering Charles into a more anti-Spanish position. See A.J. Loomie, "The Spanish Faction at the Court of Charles I, 1630-1638", Historical Research 59.139 (1986), 37-49.

${ }^{74}$ Coke's sponsorship of the printing of Mare clausum is indicated in a letter from Kenelm Digby in August 1635: “Mr. Selden's book goeth on apace in the press. I saw yesterday as much as was done. Your Honor will have thanks of all men for putting forward that piece, indeed for raising it out of the grave unto which the author had condemned it." In The Manuscripts of the Earl Cowper, KG, Preserved at Melbourne Hall, Derbyshire, vol. 2 (London, 1888), 90. For the larger political strategy of which this sponsored printing was part, see K. Sharpe, The Personal Rule of Charles I (New Haven, CT, 1992), 101-102. 
and hermeneutically, to square the poem with the more conventional and mainstream Protestant stances that Herbert assumes in his other works.

"Translation into Latin", as Carolyn Dinshaw puts it, "aims at discovering and restoring the glory of the classical past that has departed through translatio imperii." 75 For Anglo-Latin poets working within the gunpowder epic tradition - a genre defined by its nationalist aims - the choice to write in Latin speaks to a related impulse: not, perhaps, to reverse, but rather to arrest the onward movement of imperium. These vigorous poetic defenses of the English nation and English church - of the kind Herbert's generic predecessors had produced - sought to solidify English interests in two ways: by crafting highly public art, appropriate for circulation abroad, in praise of England; and by enshrining events of recent English history in the Vergilian structures of epic, in language that was itself a form of Vergilian emulation. For these poets, the decision to write in Latin was, somewhat paradoxically, a way to advertise and advance national interests, both within England and abroad. More broadly, this poetic school provides a counter-narrative to the scholarly commonplace that vernacularity was an essential component of early modern nationalism. The poem's emanation from - and afterlife within - the subgenre of the miniature epic raises striking questions counterintuitive, perhaps, to readers who have primarily considered the poem in relation to the English verse of The Temple - about why Herbert chose not to compose The Church Militant in Latin. We have suggested that the poem's anti-institutional and, therefore, unpatriotic content rendered it unsuitable for circulation within the international subgeneric and linguistic networks favored by Herbert's forerunners, who drew, in creating their brief epics, on the long association between nationalism and the classical epic. Understood in this context, Herbert's poem defiantly vernacular, defiantly westward-looking - instead resisted, in both medium and message, the forms of international advocacy on behalf of the English church in which he had engaged earlier in his career. These forms of defiance - linguistic, generic, and political come clearly into view only by considering the poem in relation to the Neo-Latin matrix from which it sought so vigorously to break.

${ }^{75}$ C. Dinshaw, Chaucer's Sexual Poetics (Madison, WI, 1989), 149. 


\section{Appendix}

Since there is no edition offering both Ecclesia militans and The Church Militant, we are reprinting the two texts on facing pages here. The English text is taken from the edition by Helen Wilcox (see n. 2). Leeke's Latin has been transcribed from Durham Cathedral Library's ms. Hunter 27, f. 190r202r (D). It has been published previously by Sebastian Köppl (see n. 31), whose readings are reported in the apparatus with the siglum $\mathbf{k}$. We have only slightly adapted spelling and punctuation. In verses 33, 105, 146, 302, and 327 the manuscript displays an unusual equals sign separating composites $(r e=$ infigere, bona $=$ nuntia, male $=$ olentia, male $=$ suada, ante $=$ ambulo $)$.

\section{George Herbert, The Church Militant}

Almightie Lord, who from thy glorious throne

Seest and rulest all things ev'n as one:

The smallest ant or atome knows thy power,

Known also to each minute of an houre:

Much more do Common-weals acknowledge thee,

And wrap their policies in thy decree,

Complying with thy counsels, doing nought

Which doth not meet with an eternall thought.

But above all, thy Church and Spouse doth prove

Not the decrees of power, but bands of love.

Early didst thou arise to plant this vine,

Which might the more indeare it to be thine.

Spices come from the East; so did thy Spouse,

Trimme as the light, sweet as the laden boughs

Of Noahs shadie vine, chaste as the dove;

Prepar'd and fitted to receive thy love.

The course was westward, that the sunne might light

As well our understanding as our sight.

Where th' Ark did rest, there Abraham began

To bring the other Ark from Canaan.

Moses pursu'd this: but King Solomon

Finish'd and fixt the old religion.

When it grew loose, the Jews did hope in vain

By nailing Christ to fasten it again.

But to the Gentiles he bore crosse and all,

Rending with earthquakes the partition-wall: 


\section{James Leeke, Ecclesia militans}

Summus ab aethereis totum qui conspicis orbem sedibus, aspectumque pari moderaris habena, te, Deus alme, tuam resonat formica potentem dextram, te minima agnoscunt momenta fugacis horae, et quot radiis lustrat corpuscula Phoebus. At quibus aeternas posuit mens provida leges plus Numen Populus colit, agnoscitque verendum: exequitur tua fata suo, gens nescia Fati, arbitrio, atque tuum quicquid decreverat olim consilium, studio repetens aeterna recenti.

Scilicet hinc hostis non est Ecclesia duri brachia, sed sponsi cupidos experta lacertos. Hanc nondum lucente die, tua dia, futuram sanguine purpuream, plantavit gratia vitem, quo ferveret Amor. Orientem ut aromata Solem agnoscunt genitorem, et odoribus ora Sabaeis nostra beant, Tiphyn pressantia; sic tua sponsa, syderea vel luce prior, vel turture fido castior et grata potior dulcedine, quam ipsa fronde nitens patula Noachanae filia vitis, fugit in occasum (Peregrina) paratior inde, solares fugiendo, tuos pateretur ut ignes.

Nempe iter huc tendit, seras ubi fixerat arces vesperus, ut radio Phoebi comitante ministro, utraque lux utrasque simul dispellere longum hinc tenebras (illas minus, has mage) posset opacas. Naturae custos ubi constitit Arca fidelis, mirandae hinc aliam fidei Pater inclytus arcam finibus a diri coepit deducere Chami.

Signifer hanc auxit Moses; Rex pacis adauctae firmavit veterem meliori indagine Cultum; Isacidae stulto tentant conamine, fixo cum Christo tremulum tristi reinfigere ligno. Ast lignum hoc vitae ad gentes crucifixus et Arcam gestat, inassuetis concusso motibus orbe, et ruptis, quibus est partita Ecclesia, septis. 
Onely whereas the Ark in glorie shone,

Now with the crosse, as with a staffe, alone,

Religion, like a pilgrime, westward bent,

Knocking at all doores, ever as she went.

Yet as the sunne, though forward be his flight,

Listens behinde him, and allows some light,

Till all depart: so went the Church her way,

Letting, while one foot stept, the other stay

Among the eastern nations for a time,

Till both removed to the western clime.

To Egypt first she came, where they did prove

Wonders of anger once, but now of love.

The ten Commandments there did flourish more

Then the ten bitter plagues had done before.

Holy Macarius and great Anthonie

Made Pharaoh Moses, changing th' historie.

Goshen was darknesse, Egypt full of lights,

Nilus for monsters brought forth Israelites.

Such power hath mightie Baptisme to produce

For things misshapen, things of highest use.

How deare to me, O God, thy counsels are!

Who may with thee compare?

Religion thence fled into Greece, where arts

Gave her the highest place in all mens hearts.

Learning was pos'd, Philosophie was set,

Sophisters taken in a fishers net.

Plato and Aristotle were at a losse,

And wheel'd about again to spell Christ-Crosse.

Prayers chas'd syllogismes into their den,

And Ergo was transformed into Amen. 
Quum tamen Arca vetus nuper splendore stupendo emicuit, Nova iam, tenui quasi fulta bacillo, it cruce, sola, pedes, Peregrina, ignota, capessens occiduos sine luce locos, petit ostia pulsu omnia, ut optato caput inclinaret in antro. At velut Hesperiis festinans Phoebus in undis tingere flammigerum caput, haud post terga relictum destituit penitus fugitivo lumine mundum, horrendam donec taciturna crepuscula noctem induxere polis: sic, sic, Ecclesia seros deflectens invita gradus, respexit amata littora, praeteritae vestigia lucis Eois diffundens populis, donec lux utraque tandem viderat occiduum, quo cingitur India pontum. Excipit hanc primo venientem limine Divum Memphis amans, quondam commoti Numinis iram prodigiis experta stupendis, nunc et amorem. Iam pia plus denas coluerunt pectora leges, quam denis quondam stupuissent territa plagis. Sancti Macarii (sileat miracula Memphis caetera) et Antonii Pharao, conamine, Moysen induit; hinc solitam seriem mutasse feruntur multa suam: tetrica infoelix caligine Goshen clauditur, et nullam patitur gens Memphica noctem. Horrendos pariens septeno flumine foetus amnis, alit veros nunc divo semine sanctos. Munera tanta novi potuit Baptisma lavacri fundere, de rabidis generare potissima monstris.

Consilia, oh, quam sunt nobis tua chara! Potentem quis valet exaequare Iehovam?

Inde lares petit Argolicos, incerta locorum, Relligio: hic ipsi cedunt in mentibus Artes humanis; stupuit sapientia tota, loquaces subdola (mirandum!) captabant retia pisces; qui sapuere polum, terras, elementa, planetas, omnia, nunc scioli tentant elementa novelli grammatis, atque alium veluti volvuntur in axem. Sic Probo cum ratione sua insanire iubetur, et caput insipidum latebrosis condere in antris; scilicet arguitur precibus, non Ergo probatam, oratam potius sequitur Conclusio partem. 
Though Greece took horse as soon as Egypt did,

And Rome as both; yet Egypt faster rid,

And spent her period and prefixed time

Before the other. Greece being past her prime,

Religion went to Rome, subduing those,

Who, that they might subdue, made all their foes.

The Warrier his deere skarres no more resounds,

But seems to yeeld Christ hath the greater wounds,

Wounds willingly endur'd to work his blisse,

Who by an ambush lost his Paradise.

The great heart stoops, and taketh from the dust

A sad repentance, not the spoils of lust:

Quitting his spear, lest it should pierce again

Him in his members, who for him was slain.

The Shepherds hook grew to a scepter here,

Giving new names and numbers to the yeare.

But th' Empire dwelt in Greece, to comfort them

Who were cut short in Alexanders stemme.

In both of these Prowesse and Arts did tame

And tune mens hearts against the Gospel came:

Which using, and not fearing skill in th' one,

Or strength in th' other, did erect her throne.

Many a rent and struggling th' Empire knew,

(As dying things are wont) untill it flew

At length to Germanie, still westward bending,

And there the Churches festivall attending:

That as before Empire and Arts made way,

(For no lesse Harbingers would serve then they)

So they might still, and point us out the place

Where first the Church should raise her down-cast face. 
Dorica quantumvis sub eodem et Memphica tellus, Relligionis iter captabat tempore, et orbis

Roma caput; cursum accelerasse putatur equino

Dorica, Pegaseo sed praeceps Memphica tergo vecta, dieque prior misera est defuncta supremo. Deficiente dein Graiae telluris honore, Romam abit, Hesperium septem de montibus orbem prospiciens, ut cui dominandi iniusta libido crevit in invidiam, audenti iuga poneret Urbi, vulneribus miles plagisque superbus hiulcis, plura videt, maiora fatetur vulnera Christi, vulnera sponte sua passi, quo panderet hortum daemonis occlusum insidiis, ubi flore perenni quatuor ex uno maduerunt flumine terrae. In cineres generosa manus fortissima vertens, longe alios abit in cineres, spolia ampla referre impurae Cytheraeae horrens, hastilia ferro aspera sternit humi, medium ne iratus in hostem dum ruit, in charis posset transfigere membris hunc, qui se aeterna periturum morte, redemit. Induit incurvum hic tremulum quassantia mundum sceptra pedum, Latio numerantia nomine menses. Graia tamen gessit Domus Imperialia summi iura throni, gentis solatia parva misellae, quando Philippaei periisset gloria regni. Imperiis in utrisque animorum heroica virtus, blandidulaeque artes, hominum contraria mulcent pectora, venturi ut caperent bonanuntia Christi.

Queis freta, hanc neque vi metuentia, easque valere posse dolis, solium condunt victricia pactum.

Plurima turbatum vario molimine sensit imperium (ut solita extremum spirantia) longum schismata, Teutonicas donec delapsa per oras, declinasset in occasum, quo ferret honorum munera, dum faceret sacras Ecclesia pompas; quo velut imperium faciles praestraverat, artesque ante vias (alios haud tanto nomine dignos norat Epistathmos), ita possent sternere eodem iure novas, digito ac sedes monstrare quietas, sub quibus erigeret demissum Ecclesia vultum. 
Strength levels grounds, Art makes a garden there; Then showres Religion, and makes all to bear.

Spain in the Empire shar'd with Germanie,

But England in the higher victorie:

Giving the Church a crown to keep her state,

And not go lesse then she had done of late.

Constantines British line meant this of old,

And did this mysterie wrap up and fold

Within a sheet of paper, which was rent

From times great Chronicle, and hither sent.

Thus both the Church and Sunne together ran

Unto the farthest old meridian.

How deare to me, O God, thy counsels are!

Who may with thee compare?

Much about one and the same time and place,

Both where and when the Church began her race,

Sinne did set out of Eastern Babylon,

And travell'd westward also: journeying on

He chid the Church away, where e're he came,

Breaking her peace, and tainting her good name.

At first he got to Egypt, and did sow

Gardens of gods, which ev'ry yeare did grow

Fresh and fine deities. They were at great cost,

Who for a god clearely a sallet lost.

$\mathrm{Ah}$, what a thing is man devoid of grace,

Adoring garlick with an humble face,

Begging his food of that which he may eat,

Starving the while he worshippeth his meat!

Who makes a root his god, how low is he,

If God and man be sever'd infinitely!

What wretchednesse can give him any room,

Whose house is foul, while he adores his broom?

None will beleeve this now, though money be

In us the same transplanted foolerie.

Thus Sinne in Egypt sneaked for a while;

His highest was an ox or crocodile, 
Aequat humum Virtus, teneris Ars floribus hortum ornat; Relligio faecundo depluit imbre.

Vendicat Imperii Germania, Iberia partem, maior at Angliacam decorat victoria gentem; quae prima, ut retineret eandem Ecclesia sortem, regali eximiam cinxit diademate frontem.

Scilicet in sacra, hoc, caelorum fata, propage, Constantine, tua, magnis oriunde Britannis, videre, ac celanda olim haec mysteria chartis clausa dedere Chrono servanda; abscissa sed inde venere Imperii certa huc monimenta futuri. Utraque sic Ortum iunctis lux alma quadrigis deserit, ignotumque olim conscendit in orbem.

Consilia, oh, quam sunt nobis tua chara! Potentem quis valet exaequare Iehovam?

Relligio cursum qua tempestate locoque ceperat, Impietas, patria Babylone relicta, coepit ad occasum gressus glomerare superbos; persequitur clamosa, fugat, strepituque fugatae exprobat, illudens violatae crimine famae. Occupat ut Memphin, veneranda ibi semine spargit Numina gramineo; rediere haec sparsa quotannis foeta, faceta, pium magno bovis excremento foecundante solum. Oh, bis prodigus iste, voraces cui subit a Divo cohibere legumine dentes! Ah, vaga mens! Quae te, dominari in caetera natam, gratia deseruit? Tibi quae dementia pectus fascinat, ut votis, animo cum corpore flexo, allia supplicibus maleolentia sollicitares!

Esurias, ne Numen edas! Venereris, hiantem quod natum est trepidi ingluviem saturare rogantis! Cum sit tanta Dei atque hominis distantia, summum, dicite, quantillus, cui fit Radicula Numen?

Quam stupide miser est, cui squallent sordibus aedes, ad sua dum nitido procumbit spartia gestu? Nulla fides dictis, quasi transplantata migrarit huc licet in similem Regina Pecunia Divam. Inter Niligenas se haud multo tempore fallax mentibus insinuat mortalibus. At pudibunda hactenus Impietas: tum summis aucta trophaeis, quum Crocodilo animos, tumido aut bovis incremento, 
And such poore game. Thence he to Greece doth passe,

And being craftier much then Goodnesse was,

He left behinde him garrisons of sinnes

To make good that which ev'ry day he winnes.

Here Sinne took heart, and for a garden-bed

Rich shrines and oracles he purchased:

He grew a gallant, and would needs foretell

As well what should befall, as what befell.

Nay, he became a poet, and would serve

His pills of sublimate in that conserve.

The world came in with hands and purses full

To this great lotterie, and all would pull.

But all was glorious cheating, brave deceit,

Where some poore truths were shuffled for a bait

To credit him, and to discredit those

Who after him should braver truths disclose.

From Greece he went to Rome: and as before

He was a God, now he's an Emperour.

Nero and others lodg'd him bravely there,

Put him in trust to rule the Roman sphere.

Glorie was his chief instrument of old:

Pleasure succeeded straight, when that grew cold.

Which soon was blown to such a mightie flame,

That though our Saviour did destroy the game,

Disparking oracles, and all their treasure,

Setting affliction to encounter pleasure;

Yet did a rogue with hope of carnall joy

Cheat the most subtill nations. Who so coy,

So trimme, as Greece and Egypt? yet their hearts

Are given over, for their curious arts,

To such Mahometan stupidities,

As the old heathen would deem prodigies.

How deare to me, O God, thy counsels are!

Who may with thee compare?

Onely the West and Rome do keep them free

From this contagious infidelitie.

And this is all the Rock, whereof they boast,

As Rome will one day finde unto her cost. 
luserat, aut simili. Littus petit inde Pelasgum, et Pietate dolis longe versutior, agmen

praesidio scelerum locat, horrendamque catervam quo miseras valeat retinere tyrannide gentes, quas nova quaeque truci addiderat victoria regno. Iam vires firmata capit, iam viribus audax, aurea templa sacrat, Tripodas habet, erigit aras, quae diram foveant scelerum, velut area, Pubem, (haud de plebe pecus) gestit speciosa, superba, compta, nitens, dubia proferre oracula sorte, fit vates, pedibus solvit mendacia strictis, laethiferum his pilulis docta immiscere venenum. Sortilegam levis hanc mundus glomeravit ad aedem, incerta ut certo pretio responsa reportet.

Nempe quid haec, nisi sub speciosa condere fraudes pelle Lycaonias? Aliquot veracia, in escam pigmentis miscet, tantis ut honoribus hostem fuscaret quemvis post se meliora ferentem. Romam abit hinc; modicum ut Danais in sedibus ante Numen erat, Latium hic audax dominatur in orbem. Huic Nero Luxurians aliique Palatia monstrant, excipiunt, Latiamque iubent captare coronam.

Facta superba olim est, bellorum et honoribus aucta, qui simulac tepuere, loco ferventia mittit castra Venus, tanto flagrantia protinus aestu, ut quamvis caecasque faces, et inertia Amorum noster in adventu turbasset proelia Soter, discutiens fanis oracula, scruta prophanis, dura voluptati opponens, et acerba secundis, en, vagus, auspicio Veneris, subtilibus Erro gentibus imposuit. Doctis quae terra Mycenis cautior, Aegyptove politior. Improba at horum pectora luxurians magicarum inventio rerum prodidit, Antichristicolarum admittere cultus horribiles, veterumque fidem superantia monstra. Consilia, oh, quam sunt nobis tua chara! Potentem quis valet exaequare Iehovam?

Occiduos tantum tractus, urbemque Quirini nulla superstitio foedat, contagio nulla.

Gloria et haec tota est Romanae gentis; at olim sentiet hanc vacuam laceris miseranda capillis. 
Sinne being not able to extirpate quite

The Churches here, bravely resolv'd one night

To be a Church-man too, and wear a Mitre:

The old debauched ruffian would turn writer.

I saw him in his studie, where he sate

Busie in controversies sprung of late.

A gown and pen became him wondrous well:

His grave aspect had more of heav'n then hell:

Onely there was a handsome picture by,

To which he lent a corner of his eye.

As Sinne in Greece a Prophet was before,

And in old Rome a mightie Emperour;

So now being Priest he plainly did professe

To make a jest of Christs three offices:

The rather since his scatter'd jugglings were

United now in one both time and sphere.

From Egypt he took pettie deities,

From Greece oracular infallibilities,

And from old Rome the libertie of pleasure

By free dispensings of the Churches treasure.

Then in memoriall of his ancient throne

He did surname his palace, Babylon.

Yet that he might the better gain all nations,

And make that name good by their transmigrations;

From all these places, but at divers times,

He took fine vizards to conceal his crimes:

From Egypt Anchorisme and retirednesse,

Learning from Greece, from old Rome statelinesse:

And blending these he carri'd all mens eyes,

While Truth sat by, counting his victories:

Whereby he grew apace and scorn'd to use

Such force as once did captivate the Jews;

But did bewitch, and finely work each nation

Into a voluntarie transmigration.

All poste to Rome: Princes submit their necks

Either t' his publick foot or private tricks. 
Quum penitus Cultum haud dare terga coegerit omnem

Impietas operosa fugae, furibunda virago

nocte novum facinus versabat; nempe vicissim

sacricolam simulare, sacram ostentando tiaram.

Proh scelus! Impostrix, lena execranda, putari

gestiit Expositrix rerum importuna Sacrarum.

Traiiciens oculum per scissa foramina, vidi musaeolo intentam libris, discrimina oborta volventem; Calamus decuit Pecus, Ausoniaeque dona severa togae; constantis gratia vultus non Erebo, at caelis oriundos prodidit ignes.

At Graphidi appensae mittit transversa subinde lumina, et inventum repetit sub imagine cultum. Garrulam ut hanc quondam mirata est Graecia vatem, Romaque summisit collum huic Saturnia Regi, aucta sacerdotiis, ita nunc subsannat, et effrons ludificat triplici perfunctum munere Christum; idque magis, quoniam tria vaframenta locorum praestigiosa trium, Romam accersisset in unam. Nempe Semiramia leviuscula Numina Memphi huc agit, Argolicis fatorum oracula templis.

Otia Roma dedit, Veneremque antiqua; quid obstat?

Condiderat plenum hic meritorum Ecclesia fiscum.

Tum simul, antiquae redivivo crimine sedis, sis, inquit, Babylon redivivo nomine dicta.

Fortius at populos sibi devinciret ut omnes, firmaretque novum confusa migratio Nomen, omnibus his accepta tulit, nec tempore eodem, queis tegat horrendos scelerum larvalia mores; secessum Aegyptus largita, mathemata fallax Graecia, magnificam Roma antiquissima Pompam.

His rapit admixtis cunctorum lumina, partos, dum prope victa sedet Pietas, numeratque triumphos. Turgescit facile hinc, temnens, ut inutile, ferrum, quo semel Isacidas fregit dominata superbos. Fascinat at totum occultis spontanea mundum, blandula, praestigiis Latio dare colla capistro. Omnes Romam adeunt; sacra submittuntque superbis reges Romuleae pedibus sua colla cathedrae; 
It did not fit his gravitie to stirre,

Nor his long journey, nor his gout and furre.

Therefore he sent out able ministers,

Statesmen within, without doores cloisterers:

Who without spear, or sword, or other drumme

Then what was in their tongue, did overcome;

And having conquer'd, did so strangely rule,

That the whole world did seem but the Popes mule.

As new and old Rome did one Empire twist;

So both together are one Antichrist,

Yet with two faces, as their Janus was,

Being in this their old crackt looking-glasse.

How deare to me, O God, thy counsels are!

Who may with thee compare?

Thus Sinne triumphs in Western Babylon;

Yet not as Sinne, but as Religion.

Of his two thrones he made the latter best,

And to defray his journey from the east.

Old and new Babylon are to hell and night,

As is the moon and sunne to heav'n and light.

When th' one did set, the other did take place,

Confronting equally the law and grace.

They are hells land-marks, Satans double crest:

They are Sinnes nipples, feeding th' east and west.

But as in vice the copie still exceeds

The pattern, but not so in vertuous deeds;

So though Sinne made his latter seat the better,

The latter Church is to the first a debter.

The second Temple could not reach the first:

And the late reformation never durst

Compare with ancient times and purer yeares;

But in the Jews and us deserveth tears. 
(est ea frons Monstri) turgentem forte gonagra, pertaesamve viae, Ausoniave insurgere pelle

haud decuit gravidam; validos habet ergo ministros, intus Patricios simulantes, innocua extus, nil scelerum e puris meditata animalia claustris: non hastas, non ferra vibrant, non tympana pulsant, victricesque domant linguarum murmure terras.

Sicque regunt, videas, invectum Regibus orbis pontificem, ut stolidi strigoso tergore muli. Ut nova cum veteri Imperium migravit in unum Roma, ita cum veteri nova in unum abit Antichristum; bifrontem tamen ut Deus horum claviger olim qui sua terga videt, tua in his specularia, Roma. Consilia, oh, quam sunt nobis tua chara! Potentem quis valet exaequare Iehovam?

Sic agit occidua indubios Babylone triumphos Impietas, albos fallax induta colores.

Altius e binis Solium hoc, quo penset Eois a populis nimium longi dispendia cursus. Ut caelo est lucique vices repetundo perennis Cynthius, et nocturna soror: nova cum Babylone sic veteri Babylon orco horrendisque tenebris.

Memphica ut occubuit, surgit Romana, coercens legis Evangeliique pari conamine motus. Hae Barathri lapides, Sathanae duplicata corolla, pascentesque scelus Phoebo sub utroque Papillae. Utque typum in vitiis transcriptum imitatio vincit aemula, praecedens at virtus nescia vinci: sic sceleri licet aucta thronis sint Regna superbis, temporibus debet sera haec Ecclesia priscis.

Ac veluti memorans Salomonica templa, nitorem haud restituens similem reparandis, sedulus Ezra conditor erubuit, pudibunde conscius: horret sic tot ruderibus renovata Ecclesia abactis nupera, componens annis sua tempora priscis; concipit Hebraei hinc mens ambitiosa dolorem, cogit et hoc oculis lachrymarum flumina nostris. 
Nay, it shall ev'ry yeare decrease and fade;

Till such a darknesse do the world invade

At Christs last coming, as his first did finde:

Yet must there such proportion be assign'd

To these diminishings, as is between

The spacious world and Jurie to be seen.

Religion stands on tip-toe in our land,

Readie to passe to the American strand.

When height of malice, and prodigious lusts,

Impudent sinning, witchcrafts, and distrusts

(The marks of future bane) shall fill our cup

Unto the brimme, and make our measure up;

When Sein shall swallow Tiber, and the Thames

By letting in them both pollutes her streams:

When Italie of us shall have her will,

And all her calender of sinnes fulfill;

Whereby one may foretell, what sinnes next yeare

Shall both in France and England domineer:

Then shall Religion to America flee:

They have their times of Gospel, ev'n as we.

My God, thou dost prepare for them a way

By carrying first their gold from them away:

For gold and grace did never yet agree:

Religion alwaies sides with povertie.

We think we rob them, but we think amisse:

We are more poore, and they more rich by this.

Thou wilt revenge their quarrell, making grace

To pay our debts, and leave her ancient place

To go to them, while that which now their nation

But lends to us, shall be our desolation.

Yet as the Church shall thither westward flie,

So Sinne shall trace and dog her instantly:

They have their period also and set times

Both for their vertuous actions and their crimes. 
Quin simul usque novis fugiens flaccescet in annis, adventum donec Christi caligo supremum, ut primum, excipiet mundum extinctura ruentem. Haec mensura tamen fidei assignanda ruinis casurisque datur, quanta intervalla locorum prospicit inter se ac mundum Iudaea remotum. Sentitur Pietatis apex: alata supremo ungue premit nostram hanc tellurem, ad America vergens littora; quum Baccho, Veneri, Geniisque litatur omnimodis, odia in furcas rumpentia, et effrons peccatum, lamiae, Circeaque murmura, dirae perfidiae (horroris certissima signa futuri) nostra perimplerint ad apertas pocula fibras; Sequana quando rapax saturabit Tibridis unda ingluviem, Thamisisque procis utrisque receptis intactas putido vitiabit flumine Nymphas, quando nova hanc quatiet malesuada tyrannide gentem Ausonia, et veteres repetito crimine fastus farserit, ut liceat venturo dicier anno, quod Gallis scelus, et fractis dominabitur Anglis: tunc, tunc occiduos exul properabit ad Indos Relligio; subeunt horum foelicia nostris tempora temporibus. Deus alme, his providus omnem dempsisti remoram, laceratae hinc fulva parentis viscera mittendo, dirae irritamina culpae.

Nam male conveniunt, nec in una sede morantur auri sacra fames, et Gratia, sacra salutis esuries: humiles amat haec paupercula cellas.

Credimur (ah stulti ac miseri!) his spolia ampla referre, dum proprias violamus opes, captamus eorum stercora, dum nostris ditescit America gemmis. Tu Deus hanc, nostra est quanta usque inimicia, litem diripies, indulta iubens ut gratia nobis hactenus, antiquis tandem volitaret ab aris, iustaque pro illatis persolvat debita furtis; foenora dum nostris ea gens crudelia rebus occupat, in longas nobis cessura ruinas. Quum tamen occiduos sera hinc Ecclesia tractus attigit, Impietas premet huic velocior iisdem tergora vestigiis; sua pro virtutibus istos certa manent miris, diris sua tempora culpis. 
And where of old the Empire and the Arts

Usher'd the Gospel ever in mens hearts,

Spain hath done one; when Arts perform the other,

The Church shall come, \& Sinne the Church shall smother:

That when they have accomplished their round,

And met in th' east their first and ancient sound,

Judgement may meet them both \& search them round.

Thus do both lights, as well in Church as Sunne,

Light one another, and together runne.

Thus also Sinne and Darknesse follow still

The Church and Sunne with all their power and skill.

But as the Sunne still goes both west and east;

So also did the Church by going west

Still eastward go; because it drew more neare

To time and place, where judgement shall appeare.

How deare to me, O God, thy counsels are!

Who may with thee compare? 
Et siquidem Imperii sacra vis anteambulo, et Artes, straverat usque vias animis horrentibus olim posse sacram captare fidem, gens praestitit illud Celtiberi; reliquum quando volventibus annis

Ars dederit, sacros Ecclesia pura triumphos

huc aget: inde fidem extinguet Culpa invida puram, ut nempe impletum simulac mens utraque in orbem aemula volvetur, primum et certamina ad ortum ultima committent belli, aggrediatur utramque vindex iudicium, et terebranti fulmine verset. Utraque sic mundi radiantia lumina iisdem claris conveniunt, Sol atque Ecclesia, Metis. Utraque sic horrendum, ingens, cui lumen ademptum peccatum, premit, et caeco aufert lumina mundo. Quin velut Hesperio dum mergit in axe caballum Cynthius aerium, emergit, camposque tuetur Hesternos; ortus pariterque Ecclesia primos, dum petit occasum, repetit; tempusque locusque invitant, rapidis cedent quibus omnia flammis.

Consilia, oh, quam sunt nobis tua chara! Potentem quis valet exaequare Iehovam?

4 minima] minimae $\mathbf{k} \| 8$ fata] stata $\mathbf{k} \| 11$ duri] duxi $\mathbf{k} \| 17$ Tiphyn] Tiphiin $\mathbf{k} \| 29$ diri] dixi $\mathbf{k} \| 51$ venientem] vementem $\mathbf{k} \| 107$ pactum] partum $\mathbf{k} \| 113$ praestraverat] praestaverat D k || 125 Britannis] Brittannis D k || 135 coepit] capit $\mathbf{k} \| 150$ quantillus] quantillis $\mathbf{k} \| 152$ dum] tum $\mathbf{k} \| 171$ glomeravit] glomerabit $\mathbf{k} \| 179$ aliique] aliisque $\mathbf{D}$ $\mathbf{k} \| 180$ excipiunt] exipiunt $\mathbf{k} \| 184$ caecasque] cacasque $\mathbf{k} \| 207$ intentam] intectam $\mathbf{D}$ k || 208 Pecus] Decus k || 210 Erebo] Erebro D k || 212 repetit] repitit k || 213 Garrulam] Grarrulam D Graeculam k || 238 cathedrae] k cathredae D || 239 forte] forti k || 242 extus] extas k || 247 strigoso] strigosi $\mathbf{k}|| 258$ repetundo] reptundo $\mathbf{k}$ || 260 veteri] vetem $\mathbf{k}$ || 261 occubuit] occubit $\mathbf{k}$ || 283 tellurem] telluram $\mathbf{k}$ || 285 omnimodis] omni modis $\mathbf{k}$ || 290 ingluviem] in gluviem $\mathbf{k}$ || 292 gentem] gentes $\mathbf{k}$ || 299 hinc] hic k || 316 manent] manet D k || 320 Celtiberi] Celtibus $\mathbf{k}|| 336$ potentem] k pontentem D

Saint Joseph's College lgibson@sjcme.edu

Binghamton University jkuhn@binghamton.edu 
